Portland State University

PDXScholar

Fall 11-25-2014

\title{
Street Level Food Networks: Understanding Ethnic Food Cart Supply Chains in Eastern Portland, OR
}

Alexander G. Novie

Portland State University

Follow this and additional works at: https://pdxscholar.library.pdx.edu/open_access_etds

Part of the Food and Beverage Management Commons Let us know how access to this document benefits you.

\section{Recommended Citation}

Novie, Alexander G., "Street Level Food Networks: Understanding Ethnic Food Cart Supply Chains in Eastern Portland, OR" (2014). Dissertations and Theses. Paper 2084.

https://doi.org/10.15760/etd.2082

This Thesis is brought to you for free and open access. It has been accepted for inclusion in Dissertations and Theses by an authorized administrator of PDXScholar. Please contact us if we can make this document more accessible: pdxscholar@pdx.edu. 
Street Level Food Networks:

Understanding Ethnic Food Cart Supply Chains in Eastern Portland, OR

by

Alexander G. Novie

A thesis submitted in partial fulfillment of the requirements for the degree of

Master of Urban Studies

Thesis Committee:

Loren Lutzenhiser, Chair

Paula Carder

Nathan McClintock

Portland State University 2014 
(C)2014 Alexander G. Novie 


\begin{abstract}
Portland, OR, is the site of a unique urban food cart phenomenon that provides opportunities for small business ownership and access points for culturally specific food for the city's foreign-born and minority populations. Known as a "foodie haven," Portland also has an active sustainable food movement with engaged citizens and support from city and regional policies aimed at significantly increasing the consumption of local food. To date, there have been no in-depth studies on the sourcing habits of Portland food cart owners and whether or not these street-level actors are involved in the area's local alternative food movements (AFNs). The current understanding of the Portland food cart phenomenon is based on studies that have focused on carts and pods located in the central business district and "inner-ring" areas of the city. Areas beyond these locations (defined as Eastern Portland) are currently home to the majority of the city's growing foreign-born and minority populations. This thesis uses a situational analysis framework to explore the food supply practices of ethnic food cart owners operating in Eastern Portland cart pods. I investigate the feasibility of purchasing locally grown ingredients for use in ethnic cuisines and the degree to which cart owners incorporate the region's prevailing locavore ethics into their everyday culinary practices. Findings from this inquiry suggest that ethnic cart owners in Eastern Portland have a range of habitus, or personal dispositions and embodied knowledge, that is reflected in how they perceive the benefits of and barriers to "buying local" and the extent (if any) that they engage with AFNs in the Portland area. I assert that ethnic food cart owners in Eastern Portland are performing multiple community roles by providing access points for culturally specific cuisines for
\end{abstract}


their particular ethnic groups, while also offering exotic experiences to other residents and tourists alike. I discuss variations within the food cart phenomenon itself by highlighting the differences in design, amenities, types of access, and neighborhood customer bases of cart pods located in Eastern Portland. Finally, I discuss future research directions for understanding the dynamics of food supply chains in small-scale, direct-tovendor relationships and the implications for local and regional food sustainability policy goals. 


\section{Acknowledgements}

I would like to thank my committee chair, Dr. Loren Lutzenhiser, for his ongoing support, feedback, and supervision throughout my graduate school journey. I have also been extremely fortunate to work with the other two members of my committee, Dr. Paula Carder and Dr. Nathan McClintock. Their cross-disciplinary strengths and overall intellectual acumen have proved to be invaluable resources for this research. I would also like to acknowledge the rest of the faculty, staff, and students of the Toulan School of Urban Studies \& Planning and the College of Urban \& Public Affairs at Portland State University. There is a plethora of knowledge in those halls.

Lastly, I must give the utmost gratitude to my family and community members for all of their support. They have been fundamental to my success in graduate school, and have been incredibly supportive and also constructively critical when necessary. 


\section{Table of Contents}

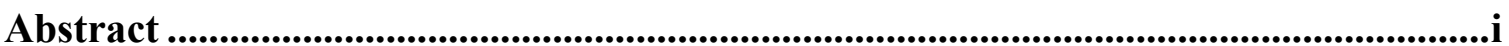

Acknowledgements ................................................................................................................... iii

List of Tables............................................................................................................................. vii

List of Figures ........................................................................................................... vii

Chapter 1: Introduction ..........................................................................................................1

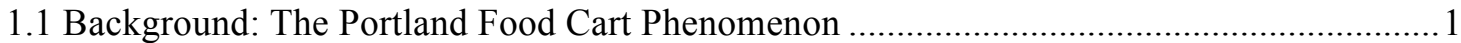

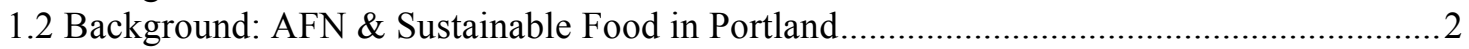

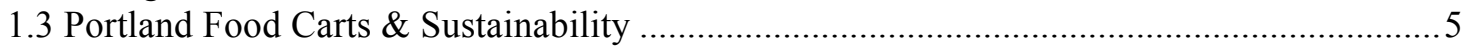

Chapter 2: Theoretical Frameworks ...........................................................................8

2.1 Critical Food Studies \& Local Alternative Food Networks ............................................ 8

2.2 Bourdieu's Relational Sociology: Understand Practices of Differentiation ........................ 11

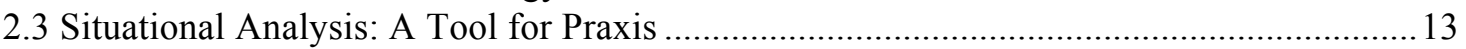

2.4 Reconciling Bourdieu's Field Theory \& Clarke's Situational Analysis .............................. 15

Chapter 3: Literature Review of Food Carts \& Food Sustainability Policies in

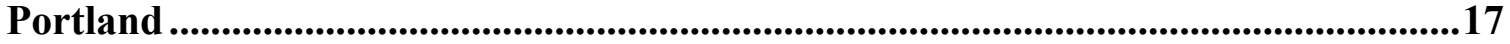

3.1 Existing Literature on the Portland Food Cart Phenomenon .......................................... 17

3.2 Alternative Food Networks \& Food Systems Policy Tools in Portland .............................20

Chapter 4: Methodology \& Data Collection .....................................................................26

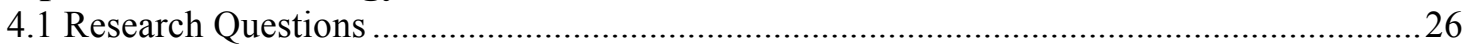

4.4 Data Collection I: Material Inventory of Food Carts in Eastern Portland ........................... 30

4.5 Data Collection II: Interviews with Ethnic Food Cart Owners ........................................... 31

Chapter 5: What the Carts Say - A Material Inventory of Food Cart Pods in Eastern Portland....................................................................................................35

5.1 Field Observations from Pods in Eastern Portland .............................................................. 40

Chapter 6: Ethnic Cuisine \& Local Food: Interviews with Food Cart Owners in

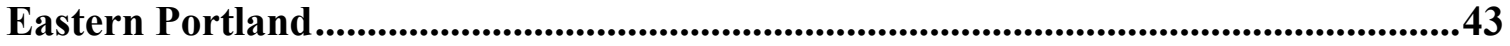

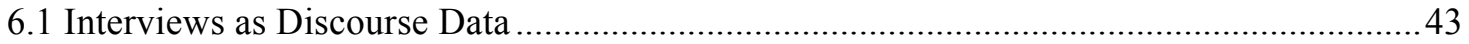

Chapter 7: A Situational Analysis of Ethnic Food Cart Supplies in Eastern Portland

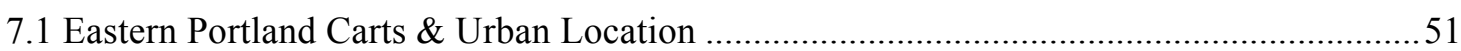

7.2 Negotiating Cultural \& Culinary Identities in Eastern Portland's Street-Level Networks ..53

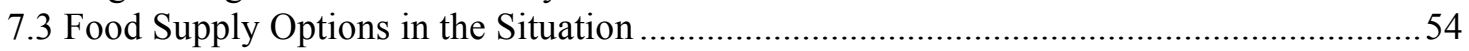

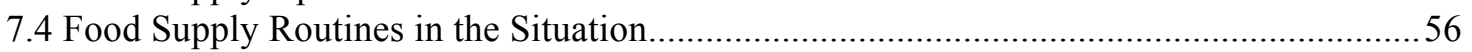

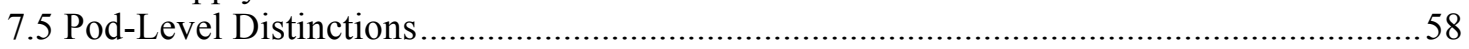

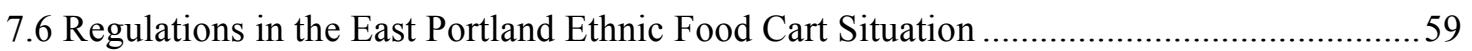

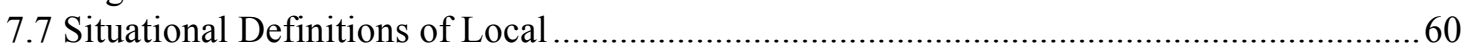

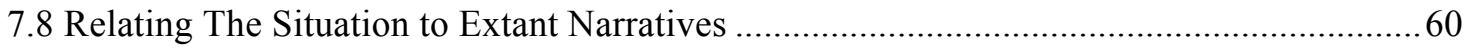

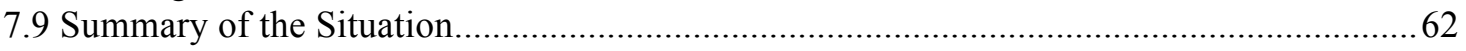

Chapter 8: Study Limitations, Implications \& Future Research Directions ..............66

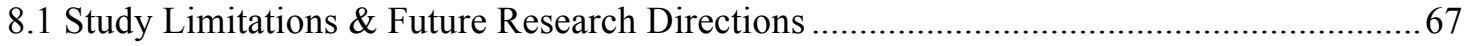


References

Appendix A: Portland Food Cart \& Demographic Maps .............................................78

Appendix B: Menu Materials from Food Carts Inventoried ....................................82

Appendix C: In-Depth Interview Guide ...........................................................8 


\section{List of Tables}

Table 1: Portland Total \& Foreign-Born Population (2009 Data). ....................30

Table 2: Inventory of Food Cart Marketing Materials in Eastern Portland................37 


\section{List of Figures}

Figure 1: Map of Food Carts Pods Inventoried in Eastern Portland.......................36

Figure 2: Map of Sidewalks \& Carts Inventoried in Portland (2010 Data).............52 


\section{Chapter 1: Introduction}

\subsection{Background: The Portland Food Cart Phenomenon}

Portland, OR is the site of a growing mobile food movement ${ }^{1}$ that has gained considerable attention in the past several years as both a unique feature of the city's artisan or craft economy (Flores, 2010; Heying, 2010) and a model of urban economic development with positive impacts for neighborhoods across the city (Chastain 2010; Kapell et al, 2008; Rogers \& Roy, 2010). In 2011, US News and World Report voted Portland number one in an international ranking of street food cities (Weiner, 2011) and continues to receive international attention from Canada to the United Arab Emirates (Associated Press, 2014). The majority of the estimated five to seven hundred food carts operating throughout the city at any given time are largely grouped into pods stationed on vacant lots, in semi-permanent arrangements that have been well received by surrounding businesses and restaurants (Flores, 2010; Hess, 2012; Kapell et al, 2008; NLC, 2013; Newman \& Burnett, 2013; Rogers \& Roy, 2010). Due to a unique regulatory environment where a "bureaucratic ease" translates into a loose interpretation of the word "mobile," food cart pods function as de-facto stationary marketplaces where vendors offer myriad culinary choices to residents and food tourists alike (Chastain, 2010; Flores, 2012; Njus, 2014; Rogers \& Roy, 2010).

Having spread throughout much of the city, these semi-stationery marketplaces each have their own mix of cuisines and cultures and are also acting as gathering sites for social events beyond food. Certain pods actively promote current menu specials, new cart arrivals, and special events such as group viewings of a Portland Trail Blazers game or an

\footnotetext{
${ }^{1}$ According to Flores (2010), there was a 40\% increase in the number of food carts in Portland from 2008 .to 2010 . 
episode of Portlandia on a big screen inside a tent complete with a beer garden and a heater. Pod locations throughout the city display unique spatial and demographic differences that often reflect the local characteristics of their surrounding neighborhoods (Neman \& Burnett, 2013). Portland food carts provide access points for culturally specific or "ethnic" cuisine for the city's growing minority and immigrant populations as well as opportunities for self-employment and small business ownership (Kapell et al, 2008; City of Portland, 2012). A 2008 survey of food carts found twenty-four different nationalities among the cart owners sampled, with a Hispanic majority outside of the central business district (Kapell et al, 2008). Even though half of the owners surveyed in this study were foreign-born, this study area did not include sites in eastern half of the city (See Appendix A for a map of this study area). Based on neighborhood coalition data for this area of Portland (CNN, SEUL, EPNO), Eastern Portland is an area of the city with the largest population of foreign-born residents in the city (City of Portland, 2014a) and a built environment that differs from the downtown and "inner-ring" neighborhoods (City of Portland, 2009 \& 2012). Hence, a large swath of the city's growing entrepreneurial class is not represented in existing studies on the Portland food phenomenon. $^{2}$

\subsection{Background: AFN \& Sustainable Food in Portland}

The Portland area is also home to a robust sustainable food movement that provides a means for residents and food service establishments to purchase food supplies

\footnotetext{
${ }^{2} 2009$ Population figures from the City of Portland estimated that $80 \%$ of city residents live east of the Willamette River. East Portland alone is $24 \%$ of the city's population (City of Portland, 2014b). Based on District Coalitions from the City's Office of Neighborhood Involvement, the area of the city inventoried in my empirical discourse analysis of food cart marketing materials (CNN, SEUL and EPNO districts) represents $60 \%$ of the city's population.
} 
grown in the fertile Willamette Valley region and distributed by a range of actors at various outlets, including regional farmers, through farmers' markets, at nearby grocers, and through community-supported agriculture arrangements (Giombolini et al, 2011; Heying, 2010). Scholarship on food systems often refers to these assemblages as alternative food networks (AFN) that encompass a multiplicity of actors, materials, ideologies and intents that seek to oppose the market conditions of the dominant industrial food system and shift power imbalances in centralized food supply chains (Allen et al, 2003; Lockie, 2009; McClintock, 2013). ${ }^{3}$ How AFNs are actually playing out in the daily lives of urban inhabitants remains a topic of discussion for critical food systems scholarship, an emerging strand of research that questions the distributional assumptions of strategies embodied by slogans like "buy local" or "farm the city" (Allen et al, 2003; Born \& Purcell, 2006; McClintock, 2013).

Food sustainability, and sustainable supply chains in particular, are an important component of the agricultural sustainability goals articulated by city and regional policymakers in the Portland metro area (c.f. the 2009 City of Portland and Multnomah County Climate Action Plan and the 2012 Portland Plan). Objective 15 of the 2009 Climate Action Plan is to "Significantly Increase the Consumption of Local Food" (City of Portland \& Multnomah County, 2010: 53). These documents demonstrate a concerted effort on behalf of policymakers to support and expand upon existing alternative food movements and integrate food systems issues into the planning process. Efforts toward increasing food supply chain sustainability for growing and consuming local and regional

\footnotetext{
${ }^{3}$ Other scholars have used the term "alternative food systems" (c.f. Kloppenburg et al, 2000; Mares \& Peña, 2011) or "local food systems" (Feagan, 2007) to describe similar networks of food production processes and social relations. While I draw on their insights, I have chosen to use the term AFN to refer to the varying strands of research. 
food are exemplary of Portland's reputation urban sustainability innovator (City of Portland, 2010; Krueger \& Gibbs, 2007). Yet, these food sustainability metrics are a relatively new policy development in Portland (City of Portland, 2009). Realizing these broad food system sustainability goals is predicated upon the effective design, implementation and measurement of specific strategies that can benefit city's increasingly diverse population. Attention to the variety array of groups involved in food production and consumption is in line with the city's commitment to equity in the crafting, implementation and evaluation of its sustainability policies and aspirations (City of Portland, 2012). Measuring the outcomes of sustainable strategies like 'increasing the consumption of local food' requires a detailed understanding of the sector involve (e.g. food carts) and how the concepts of sustainability involved (e.g. local food sourcing and access) are defined and operationalized from multiple perspectives rooted in everyday practice. A recent review of the currently available metrics for evaluating the consumption of local and regionally sourced food indicates that food supply chain sustainability metrics are in their nascent stages for many areas of the food system (City of Portland \& Multnomah County, 2012: 45).

As an agricultural sustainability solution, promoting local food is a contested topic in scholarly discussions on agricultural sustainability that, in general, highlight the need for nuanced and site-specific analyses of local food in practice by communities within a city (Allen et al, 2003; Born \& Purcell, 2006; DeLind, 2011; Feagan, 2007; McClintock, 2013; Sonino, 2010; Wilk, 2006). There is a lot we don't know about food supply chain sustainability from a policy evaluation standpoint, and considerable work to 
be done to further our collective understanding of food supply chains and the impacts of food sustainability initiatives that seek equitable access for all groups. Scholarship on how food service establishments use local and regional products in their supply chains and advertise the benefits local food to consumers has tended to focus on larger food system actors (i.e. academic institutions, grocery stores, chain restaurants) (Heying, 2008; Jonhnston, 2007; see Pullman et al, 2009 for large-scale supply chains). The City of Portland offers resources for current and prospective mobile food vendors, but these mainly relate to understanding licensing and bureaucracy, not how to ingratiate one's cart into the locavore food culture (City of Portland, 2014d). Understanding how these smallscale actors relate to larger urban movements trends is integral when assessing the distributional aspects of policies and aspirations toward increased food system sustainability.

\subsection{Portland Food Carts \& Sustainability}

To date, no systematic study has investigated how food carts source their food items, and we know very little about food cart supply chain sustainability in Portland. We lack empirical data, such as quantitative supply chains surveys or qualitative descriptions of owners' supply chain habits. Hence, most questions about food cart sustainability in Portland are inherently speculative and lack descriptions and analyses - key bases of knowledge from the social sciences that can inform policy goals, implementation, and evaluation. Quantitative metrics to understand supply chain sustainability exist for larger

entities (e.g. institutional purchasing), but the numerous and diverse nature of food cart vendors, pods and customers requires a basic descriptive understanding of their supply 
chain networks. ${ }^{4}$ Portland food cart owners represent a comparatively diverse class of business owners, offering ethnic cuisines to communities of similar ethnicities as well as other varieties of Portlanders. It is unclear of these providers of cultural tourism within in a historically White city are aware of or involved in the area's sustainability movements, and whether these movements are inclusive to and commensurate with their needs.

To begin investigating this understudied idea of supply chain sustainability and ethnic cuisine in the food cart scene, I used an iterative research design process to incorporate multiple strands of data to create a situation for analysis. This situation reflects existing and potential positions within the topics of study based on the collection of human and non-human actors involved (Clarke, 2005). I use inductive methods to provide a "thick description" of the social worlds of ethnic food cart operations in Eastern Portland ${ }^{5}$ through an iterative and abductive data collection process in two primary stages (Geertz, 1973; also cited in Clarke, 2005: xxiii). Stage one is an inventory of marketing materials at food carts $(\mathrm{n}=81)$ using Hodder's (1994) concept of material cultural as representative of discursive positions in the food cart arena (also cited in Carder, 2008). This inventory informed a second stage of data collection through open-ended, in-depth interviews $(\mathrm{n}=5)$ with food cart owners at four food cart pods in Eastern Portland. In addition to Clarke's (2005) situational analysis framework, I also drawn on Bourdieu's $(1984 ; 1998)$ sociological concepts to explore dynamics within this situation, including

\footnotetext{
${ }^{4}$ Morgan (2013) refers to this approach as "sequential priorities" design in mixed methods research, the sequence of which is determined by the extent of extant knowledge on the subject. This research can be classified as a "QUAL $\rightarrow$ quant" design, where the interpretation of a "core" qualitative study are operationalized as variables and tested for quantitative relationships among a larger sample of food cart owners as a follow-up to this inquiry (Morgan, 2013: 181).

${ }^{5}$ My definition of Eastern Portland is a combination of three easternmost neighborhood coalition districts: Central Northeast Neighbors (CNN), Southeast Uplift Neighborhood Coalition (SEUL), and East Portland Neighborhood Office (EPNO) (see Appendix A). 
the distinct everyday practices, dispositions, and embodies knowledge (habitus) and collective common sense or worldviews (doxa) of food cart owners within the larger social arenas (field) of the Portland food cart phenomenon and AFN in Portland.

This study answers a call by various researchers (c.f. Dahlberg, 1993; Feagan, 2007; Peters et al 2009) and policymakers (City of Portland \& Multnomah County) to describe and analyze relationships within the food system, with the general goal of informing reflexive policies and actions that account for geographic, demographic and cultural differences (Alkon \& Ageyman 2011; Gatrell et al 2011). ${ }^{6}$ Chapter 2 reviews the theoretical frameworks I used to understand and articulate my research questions and helped inform data collection. Chapter 3 examines the existing literature on Portland food carts with a narrative analysis of this discursive data. Chapter 4 reviews the methodological frameworks I used for abductive data collection within the Eastern Portland sample area, and outlines how mapping the discourse on Portland food carts informed my sampling of food cart owners for in-depth interviews. Chapter 5 presents an inventory of materials from food carts in 8 pods in Eastern Portland. Chapter 6 offers an interview-based account of the daily business practices and sourcing habits of food cart owners serving ethnic food in Eastern Portland. In Chapter 7, I analyze the entirety of the data gathered data based on Clarke's (2005) situational analysis theory and methods package, interpreting the elements in the situation in the context of the existing narratives on the food carts and local AFNs in Portland. Finally, I discuss limitations, implications and future research directions based on this qualitative inquiry in Chapter 8 .

\footnotetext{
${ }^{6}$ Dahlberg (1993) is credited with conceptualized food systems as orienting analytical framework in academic discourse. Specifically, his idea of a "regenerative food system" seeks to understand the interactions between the actors at various scales through a "contextual analysis" that can advance the dialogue toward more sustainable food systems (Dahlberg, 1993: 75-6).
} 


\section{Chapter 2: Theoretical Frameworks}

Three overarching theoretical frameworks that frame this investigation into the sourcing practices of food cart owners serving ethnic food in Eastern Portland and how these actors relate to the alternative food networks in the greater Portland metro area. The first is a critical food studies framework that incorporates social justice principles, which I use to interrogate assumptions of local sourcing as an alternative strategy toward food system sustainability by focusing on everyday practices and routines. The second framework is Bourdieu's $(1984,1998)$ relational theory of social fields that focuses on dialectical relationships between individual practices of food cart owners serving ethnic foods within the potentially competing fields of the Portland as a site of a unique street food phenomenon and Portland as a sustainability innovator. The third framework is Clarke's (2005) situational analysis, an integrated theory and methods package that is similar to Bourdieu's concepts of habitus in field in that it offers a means of conceptualizing, analyzing and interpreting qualitative data to reveal the positions of actors within discursive arenas. While certainly overlapping in ontological and epistemological traditions, a synthesis of these three theoretical frames helps illustrate my process of data collection and analysis and situate my site-specific research within the broader context food systems and urban sustainability scholarship. I will review each of these theoretical frames individually in order to employ a synthesis of these concepts throughout the body of this this thesis.

\subsection{Critical Food Studies \& Local Alternative Food Networks}

A growing thread of food systems scholarship produced in the last decade and a 
half has criticized the mainstream sustainable food movement ${ }^{7}$ as a privileged space of whiteness (Slocum, 2007) that can reproduce existing power imbalances (Allen, 2008 \& 2010). Dupuis, Harrison \& Goodman (2011: 296) contend that many definitions of "good food" in the U.S. reinforce the privilege of a Northern European lineage that claims to understand that practice of "... a superior middle-class lifestyle, or "habitus" (Bourdieu, 1984)." Julie Guthman (2003) uses the term "yuppie chow" to refer to food systems solutions that are not inclusive in practice. In addition, popular calls to "eat fresh" and "buy local" represent a political stance (i.e. "vote with your fork") that runs the risk of producing new consumer subjects (Alkon \& Agyeman, 2011; DeLind, 2010; Levkoe, 2011). Eschewing homogenizing or blanket solutions, this critical food studies framework pays specific attention to the multiplicity of values and differing cultural identities of the particular populations implicated in policy goals (i.e. increasing the number of farmers' markets in Portland) or as participants and/or beneficiaries of a particular movement (i.e. "locavore"). Scholars such as McClintock (2013) have questioned the distributional outcomes of novel urban economic food movements, including what Donald \& Bay-Palmer (2006) have dubbed the "urban creative-food economy" that includes quality-based, local, ethnic or organic products (p1902).

Substantive discussion on solutions designed to advance food system sustainability is often curtailed by the local/global binary that simplifies theories and complicates praxis (Born \& Purcell, 2006; Dupuis \& Goodman, 2005; Feagan 2007: 34;

\footnotetext{
${ }^{7}$ Alkon \& Agyeman (2011) identify the "mainstream" sustainable food movement as with popular authors such as Michael Pollan, Marion Nestle and Barbara Kingslover who have urged readers to shift to sustainable agriculture by buying fresh food from local farms (p2). They note how "locavore" was the Oxford English Dictionary's word of the year in 2007 (Prentice, 2007, cited in Akon \& Agyeman, 2011: 2).
} 
Wilk 2006). Born \& Purcell (2006) contend that food activists, planners and researchers tend to assume that local solutions are inherently desirable (known as the "local trap") and argue that local should be a means of improving inequalities rather than a strategy of scale alone. Sonino (2010) defends locavores and AFN practitioners, arguing that the local trap itself can be a myopic distraction. Working within existing structures to develop AFNs does not necessarily lead to a reproduction of structural inequalities. The local trap, however, is an important thought exercise and a reminder to push beyond facile rhetoric and simple binaries. Born \& Purcell would likely agree with Sonino's (2010) conclusion that "...relationships of proximity do not guarantee social fairness" (p27). Dupuis \& Goodman (2005) synthesize these ideas succinctly into a "reflexive politics of localism" that treats local food systems as a "mutually constitutive, imperfect, political process in which the local and the global make each other on an everyday basis" (p369). Furthermore, Levkoe's (2011) similar notion of "reflexive localization" calls for a "new political imaginary" in which food researchers, activists and community members alike engage with the contradictions and complexities inherent in alternative food movements that seek transformative outcomes in complex fields of action (p700).

I use the term "critical food studies" to refer to a collection of scholarship under various names that is conceptually linked together by a shared focus on the power relations and distributional outcomes of solutions and policies that purport to address to social and environmental problems while positively impacting local economies. This includes the food justice movement that specifically seeks to integrate social justice concerns into the popular sustainable food narrative. Alkon \& Agyeman (2011) define 
food justice as movement explicitly critical of barriers that inhibit communities of color from accessing local and organic food. Their goal is to "...highlight the alternative imaginings eclipsed by the pervasiveness of the food movement narrative, to offer other voices and visions of how past and present human communities relate food, agriculture, and ecology" (Alkon \& Agyeman, 2011: 7). When investigating AFNs using this framework, scholars emphasize aspects of social equity (with specific attention to race and class) and the need for more data on how alternative strategies and solutions are realized in everyday practice.

Critical food studies is conceptually linked to scholarship on the broader topic of sustainability, wherein scholars treat sustainability as an emergent field of complex social processes that must be thoroughly described and empirically investigated with the hope that sustainability-oriented policies do not merely reify structural inequalities that have created so-called "unsustainable" conditions (Krueger \& Gibbs, 2007: 4). As a historically White city experiencing an influx of immigrant and minority residents ${ }^{8}$ Portland faces real cultural changes that will test the city's commitment to equity as a fundamental orienting frame in urban policy (City of Portland, 2012).

\subsection{Bourdieu's Relational Sociology: Understand Practices of Differentiation}

French sociologist Pierre Bourdieu is credited with developing a reflexive theory of society that attempts to avoid traditional binaries of sociology, including structure/agency reductions and subjectivist/objectivist positions of knowledge (Navarro,

\footnotetext{
${ }^{8}$ According to enrollment figures by ethnicity from Portland Public Schools from 2012 and 2013, approximately 45 percent of the public school children in Portland are non-White. The largest minority group is Hispanic, representing 16 percent of enrolled students (PPS, 2014).
} 
2006; Wacquant, 2005). ${ }^{9}$ Bourdieu's key concepts of habitus, doxa, and field outline a theoretical model for understanding the "genesis and positional distribution" of social practices (Navarro 2006, 20). These concepts encompass the dispositions (habitus), collective socialized norms and tendencies (doxa) that guide the everyday behavior of individuals within certain social arenas or phenomena (fields) (Wacquant, 2005). The habitus of an individual is not fixed position but rather fluid assortment positions are both structured and structuring, reproduced through experiences and practices and subject to change over time (Navarro, 2006: 16). Habitus is constantly being redefined by both external social factors and internal and subconscious factors that affect routinized and everyday behavior (Ibid.). Doxa represents the combination of the self-evident beliefs, opinions, and unstated assumptions that are akin to the "common sense" of a social actor or group (Bourdieu, 1984, 471). The habitus and doxa of specific social actors delineate the boundaries structured spaces of collective positions, or fields, which are in constant struggle (or "battlefield" in a translation of the original French) for definition and redefinition of rules and practices (Bourdieu, 1984; Wacquant, 2005).

Habitus, doxa and field are "ingredients" in Bourdieu's formula that coalesce around the fundamental idea of differentiation into the concept of "social space" in which individuals or groups are distributed based upon their relative amounts of economic and cultural capital (Bourdieu, 1998: 6). Economic capital is defined in monetary or quantitative terms whereas cultural capital is more conceptually defined as a combination taste and values (the embodied state), cultural goods (the objectified state), and

\footnotetext{
${ }^{9}$ Wacquant (2007) refers to these binaries of classical philosophy and social theory as "inherited categories and accepted ways of thinking...in the name of culture and rationality" that amount to a "symbolic violence" perpetrated by existing structures of power (p.264).
} 
qualifications or valorizations (the institutionalized state) that are used by individuals and groups to obtain more economic capital (Bourdieu, 1986; Beasley-Murray, 2012). For Bourdieu, these forms of capital are exchanged by actors that occupy similar but distinct positions in a variety of fields.

According to Wacquant (2007: 267), habitus is a dialectical tool for unpacking the often "...segmented or conflictive dispositional sets" that are common to persons who have experienced transnational migration. ${ }^{10}$ As I mentioned earlier, Dupuis (2002) has used habitus to articulate how "perfectionist politics" associated with claims of "good food" by AFN practitioners in the U.S. are rooted in a specific Northern European history that claims on how to conduct one's lifestyle (also cited in Dupuis, Harrison \& Goodman, 2011). I use the concept habitus in this inquiry to explore how the culinary practices of foreign-born food cart owners have been structured by their places of origin as well as having been structured by their tenure in Portland and exposure to the city's rather distinct culture.

\subsection{Situational Analysis: A Tool for Praxis}

Clarke's (2005) concept of situational analysis is a theory/methods toolkit that addresses theoretical problems with qualitative research that occurred during the period after postmodernism (specifically "pure" symbolic interactionism and grounded theory) by using "the situation" as the unit of analysis (p79). Clarke highlights three main lines of thought that inform this analytical construct. The first is firmly Foucauldian in that it challenges the reductionist problem of purely symbolic interactionism (e.g. the grounded theory of Strauss \& Corbin). The second is akin to the Actor-Network Theory of Law and

\footnotetext{
${ }^{10}$ I would argue that a similar notion of segmented or dispositional sets also applies to any newcomer to Portland, even from other states within the US.
} 
Latour (among others) that gives significant importance and outright agency to nonhuman elements or actants (c.f., Latour, 2005). Third is a critical view of "social worlds" as units of analysis, which Clarke contends are too dependent on conceptualizing the social world as containers within which human actors exist and operate (e.g., the "conditional matrices" of Strauss \& Corbin). In synthesizing the three strands of thought, the situational analysis effectively eschews the notion of "context." For Clarke there is no context - context is everything and therefore the term is redundant. This epistemological claim is one of the key points of the situational analysis framework.

Clarke's tools for situational analysis help researchers enhance the transparency of what should be a rigorous and exhaustive process of inquiry. Clarke attempts to integrate situational analysis with the critical discourse analysis of Foucault, which she criticizes as too focused on the "master discourse" (Clarke, 2005: 175). Clarke's contribution is to recognize the wide variety of discourses and the silent partners in a given situation, not simply to recapitulate dominant discourses. This is especially helpful in research that uses a combination of qualitative methods (interviews, popular media, etc.) at varying scopes (i.e. region, city, neighborhood, food cart pod). Situational maps "plot" all of the elements in the situation. Ranging from messy, initial brainstorms to refined and deliberately organized maps, the point of the situational maps is to explore the relation between elements (Ibid.: 102). Following Foucault's (1973) insistence on moving beyond the "knowing subject" that is a coherent whole of one particular position, Clarke's positional maps represent specific positions in discourse. Clarke terms the positional map as a radical departure from positions as associated with persons, groups or 
institutions, as individuals can hold multiple and conflicting positions simultaneously (Clarke, 2005: 126). By mapping discourse in the situational and social worlds/arenas maps, the researcher uses the positional map as a means to analyze and represent all of the positions in the particular discourse. Important to this framework is Clarke's rejection of social science conventions such as "normal" or "deviant" positions that commit the researcher to a particular discursive outlook (Clarke, 2005: 126), and is similar to Bourdieu's deconstruction of structure and agency. Thus, the researcher seeks cognitive flexibility by representing both "seen" and "unseen" or missing positions in their data. Positions are plotted on axis and it missing positions are noted. These exercises are intended to thoroughly examine the relationships in the data, rather than isolate specific variables in the positivistic tradition of orthodox social science. Thus, researchers should be surprised by some of the connections made (Clarke, 2005: 141).

\subsection{Reconciling Bourdieu's Field Theory \& Clarke's Situational Analysis}

According to Clarke, situational analysis problematizes the social world as a container within which human actors exist and operate. To a discerning social theorist, this might seem somewhat at odds with Bourdieu's field theory. While he focuses on dialectical concepts like habitus and field that are both structured and structuring, Bourdieu is essentially attempting to model the "genesis and positional distributions of social practice" (Navarro, 2006: 20). The notion of field as I employ it in this study merely draws a boundary around a discursive arena (e.g., the Portland food cart phenomenon; AFNs in Portland), understanding that fields like the Portland food cart phenomenon are being constantly shaped and redefined by an assemblage of human and 
nonhuman actors of various assemblages. 


\section{Chapter 3: Literature Review of Food Carts \& Food Sustainability Policies in \\ Portland}

\subsection{Existing Literature on the Portland Food Cart Phenomenon}

A unique regulatory treatment of the "mobile" aspect of food cart regulations has allowed Portland food cart pods to operate as essentially stationery sites of cultural production (Kapell et al, 2008; Newman \& Burnett 2013; Rogers \& Roy, 2010). Two particular publications have focused on Portland food carts through the lenses of social justice (Newman \& Burnett 2013) and food justice (Agyeman \& Sobel, 2013). Newman \& Burnett's (2013) piece on Portland street food noted that food carts allow food vendors/creators to provision for specific communities, and are even a "method of resistance" to fast food and other traditional food service establishments (Newman \& Burnett 2013: 234). According to their research, "Street food has been promoted as a mechanism for ensuring the presence of local, healthy, and 'ethnic' foods in urban areas; to that end, some cities have implemented rules designed to ensure that vendors sell foods that conform to such goals" (Ibid: 236).

Agyeman \& Sobel's (2013) piece, while featured in the popular media publication Mobile Food News, is rooted in Agyeman's “just sustainability” concept that incorporates social justice principles in the measurement of policy goals that focuses on actual outcomes for minority immigrant populations (Alkon \& Agyeman, 2011: 6). ${ }^{11}$ The authors question the interpretation of mobile food laws as necessarily promoting social justice, noting that such policies are typically formed through "trial and error" or as a

\footnotetext{
${ }^{11}$ As evidenced by a collection of scholarship on food justice that Agyeman co-edited, "just sustainability" is very much in line with the food justice movement (Alkon \& Agyeman, 2011: 6).
} 
reaction to informal arrangements that are already taking place (this is also the interpretation of Kapell et al, 2008). Mobile food policies can be example of alternative projects that specifically benefit persons of color if such policies take into account how cultural identities are formed along with the more traditional economic measures of community development (e.g. public health and employment opportunities), in what amounts to a "multifaceted approach to measuring social justice" (Agyeman \& Sobel, 2013).

Questions of who benefits from the Portland food cart phenomenon have been asked in various forms, while others have gone largely unquestioned in formal studies. A detailed 2008 publication by Master of Urban and Regional Planning students at Portland State University used a multi-site survey to assess the impact of food carts on street vitality and neighborhood livability (Kapell et al, 2008). The authors noted that, at the time, the city lacked sufficient knowledge about the growing industry in order to guide policy and presented a cost-benefit analysis of food carts from the citizen's perspective. The study indicated, "...carts provide good employment opportunities for immigrants and low-income individuals to begin their own businesses, although there are significant barriers to continued stability and success" (Kapell et al, 2008). The authors also concluded that carts located downtown and in the central business district are more stable and profitable than carts located outside of the CBD. This is the most cited field study of Portland food carts to date (c.f. Flores, 2010; Rogers \& Roy, 2012), but it only includes three neighborhoods (Mississippi, Sellwood, Cully) outside of downtown, and no carts from East Portland. Building upon this 2008 study, Chastain (2010) compared food carts 
to small fast-food take-out restaurants in the downtown and inner-ring neighborhoods of the city from a real estate perspective. She concluded that food carts are indeed a lowercost of entry for culinary entrepreneurs, at approximately half the operating cost of small fast-food establishment of the brick-and-mortar variety.

Popular press on Portland food carts tends to focus on similar themes: the uniqueness of cart pods as sites for exotic experiences for the Portland foodie and carts as small business ownership opportunities for foreign-born and minority entrepreneurs. The Oregonian publishes an annual profile on new carts that offers local foodies a profile of the top 10 new carts and usually focuses on new exotic options (2013 included Belizean, Ethiopian, and Georgian, Mauritian) with descriptions of the "home cooking" by ethnic owners (Russell, 2013). A few other profiles include personal stories (c.f. Prichep, 2011) and, of course, a ranking of the best carts (c.f. Zimmer, 2012; Weiner, 2011). These and other foodie-oriented publications of cart (c.f. Ferretti, 2011; Travel Portland, N.d; and Rommelman, 2009) focus on the idiosyncratic nature of the food scene and having a rarefied experience. One such article, originally from the Associated Press, was reprinted in Canadian Journal Calgary Herald and the Khaleej Times publication based in Dubai, UAE (Duara, 2014).

In addition to foodies, popular press on carts is often geared toward the city's real estate community. In 2012, the Portland Business Journal, which caters to downtown business owners and operators, noted how food carts are "filling buildings as well as bellies" in downtown (PBJ, 2012). This PBJ piece referenced a report from real estate consultant Jones Lang Lasalle on how vacancy rates were "significantly lower" for cart- 
adjacent office buildings downtown (PBJ, 2012). In 2013, local news station KATU published a piece on food carts adding to the vibrancy of downtown Portland (Culverwell, 2013). These profiles of carts for foodie and real estate audiences are usually in downtown or the inner ring, save for a frequent mention of one East Portland pod (See Appendix A), which may be due to the considerable attention paid to advertising by the owners of this pod. ${ }^{12}$ Additionally, there isn't much talk about sustainable food practices such as local/regional sourcing when discussing ethnic food carts.

\subsection{Alternative Food Networks \& Food Systems Policy Tools in Portland}

The practice of particular AFN strategies is not a new to the Portland metro area, even though measuring this from a policy standpoint is a relatively recent development (City of Portland, 2012). In fact, farmers' markets, urban farming and locavore residents have become iconic representations in city's history and continued reputation as urbanDIY and craft economies (Heying, 2008). The perception of Portland as a local foodie haven has gained national and international attention, even appearing as the subject of the first episode of the popular IFC television series, Portlandia (Portlandia, 2011). A 2012 article on the show from the New Yorker magazine discussed on the show satirizes popular tropes of Portland, a city “... where patrons regularly seek elaborate assurances about the virtuousness of the food" (Tablot, 2010). Though satirical, this claim certainly has some merit, as Portland-based food service establishments like Hot Lips Pizza and Burgerville are widely known for their commitment to sourcing products from the region, as is Northwest grocer New Seasons (Heying, 2008; Taylor, 2009).

\footnotetext{
${ }^{12}$ I discuss the two East Portland pods in detail in Chapter 5.
} 
These AFNs are valuable resources of cultural capital that are not lost on the City of Portland and the Bureau of Planning and Sustainability, entities that have become quite effective at turning this cultural capital into a differentiated position among cities that nets economic capital. The 2012 Portland Plan, created to inform the city's comprehensive planning efforts, proudly advertises the development of access points for residents to obtain fresh and local food. The plan lists the city's growing number of farmers markets (20) and community gardens (25) that have emerged the span of less than two decades evidence of the city's "commitment to positive change and resilient communities" (City of Portland, 2012: 14).

The Climate Action Plan (CAP) is a joint effort between the City of Portland and Multnomah County toward advancing urban sustainability in the region. A two-year review of the CAP displays a strong policy agenda for a broad range of AFN solutions, many of which were "on track" after two years. Goal 15 of the CAP includes the following action items in various stages of progress: (i) "Integrate sustainable food system issues, and where practical, quantitative goals and metrics, into planning processes..." (action item notes mention incorporating food and climate into ecodistrict planning with a focus on measuring “...progress toward a healthy and sustainable food system”); (ii) "Identify and implement strategies encourage local food production and distribution, including providing incentives and removing regulatory obstacles" (grocery story and community garden initiatives described in the notes of this action item as strategies to “...bring affordable, healthful and local food to underserved areas”); (ii) "Develop policy and provide programmatic resources to significantly increase the 
percentage of home-grown and locally sourced..." through farmers' markets, CSAs, urban agriculture and "strategic sourcing" (400 new garden plots were built from 2009 to 2012 as part of this strategy); and (vi) "Establish quantitative metrics for food consumption of regionally sourced food" (data from farmers markets and CSAs are already tracked by the city, and additional metrics are being researched) (City of Portland \& Multnomah County, 2012: 43-45, emphasis added). Of the actions items I just mentioned, only item (vi) - establishing consumption metrics for regionally sourced food-received a progress report indicating "Action is underway, but may face obstacles" while other three (items $i$, ii and iii received an "on track for completion" status (ibid, 27$45) \cdot{ }^{13}$

In a similar vein, although perhaps less detailed and nuanced in prescriptions and action items, the 2009 food system report commissioned as part of the Portland Plan acknowledged that the city lacks a comprehensive plan goal or policies regarding food systems and food access (City of Portland BPS, 2009: 5). This report addresses food access primarily from the standpoint of residents. The report mentions how Portland area food and drink establishments are know for buying from local farmers, but it does not include food cart vendors. ${ }^{14}$

\footnotetext{
${ }^{13}$ I did not include two action items, $i v$ and $v i$, that dealt with educational opportunities and funding for extension services, respectively, as they are beyond the scope of this study. It is interesting to note that, among the six local food action items, none were awarded the highest status of "complete" but actions items related to land use updates, bicycle/pedestrian infrastructure, public recycling and urban forestry were deemed complete (City of Portland \& Multnomah County, 2012: 27-45). Curbside food waste enhancements, including the wildly successful compost collection, and a public relations campaign about food choices in "climate-friendly lifestyles" were the only two actions even remotely related to food that were deemed complete (ibid, 40-43).

${ }^{14}$ This is based on industry classifications of food service establishments. Mobile food vendors have a separate NAICS code (72233) that is not listed in included in the list of restaurant and drink establishments reviewed in this report (City of Portland BPS, 2009: 31).
} 
Based on these policy documents, the city's comprehensive planning efforts may be overlooking some of the finer grains of the food system when addressing supply chain sustainability topics like consuming more locally grown food. Food cart owners are on the City of Portland's radar (c.f. Flores 2010; Kappel et al 2008; Rogers \& Roy, 2010). The city maintains online resources for prospective cart owners related to regulatory compliance, but it's rather mute on food supply considerations (City of Portland, 2014d). Based on the content of existing studies, the city may not be looking too far beyond real estate impacts like increased foot traffic and urban aesthetics when considering these street-level actors in the food system. Given the relative diversity among food cart owners (more immigrant and minority representation, as discussed in the previous section on Portland food carts) a critical food studies perspective questions the ramifications of this omission. A 2010 blog post on the City of Portland's website wondered why the city's food cart couldn't help solve issues of access to fresh products in certain Portland area neighborhoods (City of Portland, 2010). Newman \& Burnett (2013) explore this idea briefly by questions whether standards for local sourcing would help or hinder street food in Portland (p. 36). To date, this particular discussion has been relatively mute in Portland, where generally lax regulatory enforcement effectively means that cart owners take this on themselves, or not.

The city does not mince words when acknowledging the city's overwhelmingly White history (City of Portland, 2012), a fact that should be present when discussing Portland as a model for sustainable strategies. In evaluating a recent community-based academic project that used action research methods with a food justice lens to investigate 
issues of race, class and privilege in Portland's sustainable food movement, Turner (2013) noted a decided lack of attention to race and class among local activists and initiatives within the movement. ${ }^{15}$ Participants in this series, the majority of whom were involved in the regional food system movement through vocation or volunteer work, were involved in an eight-week dialogue series (entitled "Food and Justice Dialogues: Who is at the Table?") that applied anti-oppression framework (from critical and feminist pedagogy) and a food justice lens to discuss race and class in the Portland food system. During a session focused on mapping and synthesized the group's conception of the Portland food system, participants noted several few key tensions in the food movement. Particularly relevant to this study, the group used the term "the 205 divide" to talk about sharp differences in food system feature (e.g. access to high-end groceries and farmers' markets) and general measures of sustainable living (e.g. walkability, 20-min neighborhoods) that are generally marked by the I-205 freeway in East Portland (Turner, 2013). ${ }^{16}$ Though anecdotal, the perspectives of citizens actively involved in AFN projects and food systems advocacy work are important.

One example of a supply chain-oriented AFN policy in the mobile food sector worth mentioning is the City of Toronto's “A La Cart” program, a 3-year experiment started in by the Toronto City Council in 2008 to “...introduce food carts serving ethnically diverse, nutritious foods to Toronto residents and tourists" (Hawkins \& Associates, 2011: i). Targeting underserved and vulnerable areas, an assessment of this

\footnotetext{
${ }^{15}$ This study was loosely organized around the loosely organized around the dissolution of the Portland/Multnomah Food Policy Council, which was beginning to coalesce around an operation definition of food justice, as well as a food justice dialogue series at Portland State University designed to interrupt oppression in area's sustainable food movement (Turner, 2013). I was a graduate researcher on this project. ${ }^{16}$ Other discussion points that were synthesized include how the state of Oregon is one of the hungriest states in the US, despite being a top agricultural producer (Turner, 2013).
} 
program found no evidence that the regulation of street food menus led to an increased availability of or demand for healthy and/or local food from street vendors (ibid).

Furthermore, the tight regulatory control over the more creative aspects of carts (e.g., cart design, menu items) was in conflict with the idea of increasing cultural diversity, an original premise of the "A La Cart" program (ibid: 14-15). The authors of an evaluation of this policy note how Portland's much more lassiez-faire approach to mobile regulations has actually resulted a high degree of diversity and dynamism within the food cart field (Ibid., 3).

Pointing out the existing shortcomings of policy strategies and initiatives to increase local food consumption and highlighting critiques of the sustainable food movement does not inherently disqualify any overall progress made by such policies or the valuable contributions of individuals involved in the food sustainability movement. A Krueger \& Gibbs (2007) note, the pursuit of sustainability is a complex and contingent social process that requires substantial descriptive and analytical work. My goal is to enhance the effectiveness of these complex initiatives and endeavors by offering tools of reflexive research seek out potentially marginalized groups throughout the articulation, realization and measurement of strategies and policies aimed and transforming current conditions towards more inclusive and substantive outcomes. Given the increasing diversity of growing Portland's population, it is increasingly important that we understand the cultural traditions and lived experiences of a diverse set of groups like ethnic food cart owners, and how they negotiate their positions within extant urban discourses and movements in order to make a living as a culinary entrepreneur. 


\section{Chapter 4: Methodology \& Data Collection}

\subsection{Research Questions}

There is a lack of understanding of food cart supply chains, and how sourcing is prioritized and understood by food cart owners themselves. If local/regional food sourcing initiatives are to include previously unmeasured, small scale actors like street food vendors, how might this affect the food cart as a means of economic opportunity and self-employment for immigrant and minority populations in Portland? To investigate the positionalities of ethnic food cart owners within larger and possibly competing narratives (both the food cart "phenomenon" and increasing local food consumption as an alternative food network), I employ the theoretical frameworks of habitus, doxa and field (Bourdieu, 1984 \& 1998) and the "reflexive localism" of critical food systems scholarship (DuPuis \& Goodman, 2005; Levkoe, 2011). The combination of these theoretical frames suggest that research questions should be as iterative as possible, while also realizing that these existing frames amount to a more abductive process of data collection and analysis. My research questions are as follows:

1) Are ethnic food carts in Eastern Portland a site of provisioning for the city's growing minority and immigrant populations that are concentrated in this area of the city?

- How do immigrants and ethnic minorities mobilize their cultural identities to appeal to the "foodie" culture of Portland?

2) Do food cart owners serving ethnic food in Eastern Portland purchase food supplies that are local or regional in origin?

- How does the amount and type of local food sourced vary by food type, 
season, cost, etc.?

- Are local or regional food ingredients available to these food carts owners?

- Are these food sourcing transactions direct relationships like farmers markets, intermediary food outlets that offer some regional products (e.g., Krueger's, New Seasons), or big-box grocery stores (e.g., Cash N Carry, Restaurant Depot, Fred Meyer)?

3) How is the idea of local/regional sourcing negotiated, defined, and marketed within the Portland food cart phenomenon? Does the advertising of local products vary based location throughout the city?

4) What motivating factors - such as economic gain, personal culinary taste, locavore/sustainability ethics, and customer demand -influence the sourcing decisions of food cart owners serving ethnic food in Eastern Portland?

$\circ$ Are the ideas of local food sourcing and sustainability commensurate with the business motivations of food cart owners serving ethnic food?

5) Does the region's sustainable food movement impact the daily operations of ethnic food cart owners in Eastern Portland?

\subsection{Data Collection Overview}

These research questions guided an iterative process of data collection and analysis to create "the situation" for analysis: food cart sourcing by ethnic food carts in Eastern Portland. Given the understudied nature of the specific topics of inquiry, I began the data collection process by reviewing existing data on Portland food carts, including newspaper articles, academic publications and marketing materials of cart and lot owner, 
to get a sense of the main themes portrayed, the types of carts involved and the areas of the city mentioned in these narratives. ${ }^{17}$ I used the concept of mapping narrative discourses from Clarke (2005) to understand the positions and locations articulated and not articulated in the discourse on the Portland food cart phenomenon. Concurrently, I conducted site visits to pods around the city and took field notes of my observations, focusing on ethnic varieties and looking for information on food sourcing. These produced some preliminary themes for data collection and delineated a purposive sampling frame (types of carts and pod locations) for collecting qualitative data, which was conducted in two stages. This is similar to the case study method (c.f., Yin, 2003).

\subsection{Sample Area Demographics: Eastern Portland}

Existing knowledge on food carts comes from studies that tend to focus on downtown and the "inner-ring" neighborhoods of the city. The 2008 Food Cartology study by Kapell et al included one pod east of $15^{\text {th }}$ Avenue on the east side of the (5Ways at NE $60^{\text {th }} \&$ Cully); the authors noted that of all sites they inventoried (Downtown, Mississippi, Sellwood, and Cully), Cully was the "least visually appealing" and located in a neighborhood with high crime (p23). ${ }^{18}$ Preliminary site visits to pods around the city revealed additional differences in physical form of the pods (pods with no seating vs. pods with ample amenities like covered seating with heaters and big-screen televisions), the types of customers (businesspersons and families), the types of cuisine offered and how it was differentiated (i.e. expensive gourmet cart vs. taco truck) and other aesthetic qualities that reflect variations in urban form (i.e. walk-up pods and pods with ample

\footnotetext{
${ }^{17}$ I review this literature in Chapter 3.

${ }^{18}$ The immigrant owner interviewed by Kapell et al (2008) stated that crime rate is an ongoing issue in the neighborhood. 
parking spaces; pods surrounded by downtown high-rises and pods in mixed-use areas). ${ }^{19}$ This is also similar to observations about Portland's sustainable food movement (Turner, 2013), including the "205 divide" phrase that describes a difference in access to fresh and healthy food on either side of the freeway in East Portland. Additionally, the Portland Plan (2012) mentions the increased diversity as well as the lack of access to transit and other social services in the eastern parts of the city (p. 62).

Based on these demographic and spatial considerations, I chose to limit the sample frame to what I define as "Eastern Portland" using district coalition boundaries. The study area of Eastern Portland encompasses three of the seven Portland District Coalitions $^{20}$ that are outside of the central business district (CBD) or "inner ring" areas: Central Northeast Neighbors (CNN), Southeast Uplift Neighborhood Coalition (SEUL), and East Portland Neighborhood Office (EPNO). This area of CNN, SEUL and EPNO accounts for 59 percent of the city's population, but is home to $68 \%$ of the foreign-born residents. Table 1 displays total population and foreign-born population by neighborhood coalition (Appendix A for maps of population by district coalition area). As has been noted elsewhere (c.f. City of Portland, 2012), communities of color are undercounted as therefore these foreign-born figures are likely underestimates.

\footnotetext{
${ }^{19}$ I give in-depth descriptions of both sites in Chapter 5.

${ }^{20}$ District Coalitions provide support and services to individual neighborhood associations through the city's Office of Neighborhood Involvement (City of Portland, 2014c). 
Table 1: Portland Total \& Foreign-Born Population (2009 Data)

\begin{tabular}{|c|c|c|c|c|}
\hline $\begin{array}{c}\text { Neighborhood } \\
\text { Coalition }\end{array}$ & $\begin{array}{c}\mathbf{2 0 0 9} \\
\text { Population }\end{array}$ & $\begin{array}{c}\text { \% Total } \\
\text { Population }\end{array}$ & $\begin{array}{c}\text { Foreign-Born } \\
\text { Population }\end{array}$ & $\begin{array}{c}\text { \% Foreign- } \\
\text { Born }\end{array}$ \\
\hline NPNS & 61,041 & $10.6 \%$ & 7,520 & $10.7 \%$ \\
\hline NWNW & 50,139 & $8.7 \%$ & 4,510 & $6.4 \%$ \\
\hline SWNI & 65,602 & $11.4 \%$ & 6,120 & $8.7 \%$ \\
\hline NECN & 58,980 & $10.3 \%$ & 4,590 & $6.5 \%$ \\
\hline CNN & 46,980 & $8.2 \%$ & 7,010 & $10.0 \%$ \\
\hline SEUL & 152,239 & $26.5 \%$ & 17,570 & $25.0 \%$ \\
\hline EPNO & 138,884 & $24.2 \%$ & 22,930 & $32.6 \%$ \\
\hline $\begin{array}{l}\text { Total PDX } \\
\text { Population }\end{array}$ & 573,865 & & 70,250 & \\
\hline $\begin{array}{l}\text { Eastern Portland } \\
\text { (CNN, SEUL, EPNO) }\end{array}$ & $\mathbf{3 3 8 , 1 0 3}$ & $\mathbf{5 9 \%}$ & $\mathbf{4 7 , 5 1 0}$ & $\mathbf{6 8 \%}$ \\
\hline
\end{tabular}

Data from City of Portland (2014a).

\subsection{Data Collection I: Material Inventory of Food Carts in Eastern Portland}

Using Clarke's technique of mapping narrative discourses, I noticed several missing points (or gaps of discursive data) in terms in the overall narrative on Portland food carts from a geographic and ethnic/racial perspective. In geographic terms, there was a lack of in-depth or situated knowledge of food cart owners operating outside of the central city district and especially and the eastern areas of Portland in particular. In ethnic or racial terms, the existing literature on Portland food carts does not examine pods the more ethnically diverse areas of Eastern Portland. These perspectives are important from a social justice perspective that values the diverse everyday practices of urban inhabitants. 
Food cart pods operating in Eastern Portland at the time of inquiry were inventoried for total 81 carts in 8 total pods. ${ }^{21}$ These pods are all outside of the central business district in an area I define as Eastern Portland. This inventory examined cart materials (on-site advertising, menus, website and social media profiles) for content related to local AFNs in Portland (e.g. "local" or "fresh). Marketing materials are valuable research data by virtue of being easily accessible artifacts that are designed to communicate certain messages to the consumer/customer (Carder, 2002: 111). Advertisements serve as important historical artifacts, which are a useful tool for understanding the social interaction that takes place in the food cart pod (Hodder, 1994). This represents "mute material evidence" (Hodder, 1994: 395) and is one means by which cart owners differentiate their food offerings to entice customers.

\subsection{Data Collection II: Interviews with Ethnic Food Cart Owners}

Open-ended, in-depth interviews with cart owners serving ethnic food in Eastern Portland cart pods took place during the winter months of November 2013 through March $2014 .^{22}$ Cart owners were selected by a combination of purposive sampling (with the goal of incorporating a diverse set of ethnic origins and foods from the larger area inventoried for marketing materials) and convenience sampling (those who agreed to talk and be recorded). Interviews were conducted in English and Spanish. The five owners interviewed represented three persons outside of the United States, one minority individual serving southern food from family recipes, and one White Portland native

\footnotetext{
${ }^{21}$ I did not include carts in these pods that were not food related (one cart was a hair salon).

${ }^{22}$ This coincided with the seasonal downturn for cart business. During the initial site observations I conducted, informal discussions with various owners indicated that interviews in the summer would be particularly hard to conduct. The volume of business is at its peak during the summer and cart owners are generally hoping offset the less profitable seasons. 
serving experimental ethnic fusion cuisine. The overarching goal of the interviews was to obtain embedded (or "thick") description of business practices of food cart owners serving their unique brand of ethnic food, and whether or not they engage with the idea of "buying local" is part of their everyday practices operating a food cart.

I began this phase of the data collection process with one interview from each of the two easternmost pods inventoried, as these two pods displayed zero material signs of local or organic ingredients. I then branched out to the other pods that I had inventoried (in the Northeast and Southeast district coalitions) to increase the spatial diversity and incorporate additional types of ethnic cuisines. An interview I ended up conducting in inner Southeast Portland acted as a kind of control for my whole group of interviewees: a White Portland native who prepares a fusion of several ethnic cuisines on a rotating menu, and thus had a lot to offer on the subject of obtaining local supplies of ethnic food. The last two interviewees included two foreign-born individuals with unique cuisines at very different types of pods; the final interviewee had a cart located at the pod that was by far the most local and sustainability oriented in my inventory).

I first frequented the pods as a customer months in advance of the interviews to note initial observations and begin to construct an interview sample frame. It was not difficult to establish a rapport with most of the owners at these pods, but it was difficult to move from an agreement to participate in my study to an actual recorded interview with their informed consent. Some owners were happy to talk offhand about their business practice and even sourcing habits, but balked at the mention of signing an informed consent and agreed only to speak off the record. All but two interviews that 
ended up being recorded actually took place on the first agreed-upon time and date. Other interviews required several attempts that were met with no-shows (the owner was not present due to unforeseen circumstances), unexpected cart closures (many carts did not operate on particularly cold or rainy days, while others shut down for weeks at a time in the winter for various reasons). ${ }^{23}$

Conversational style was used to encourage cart owners to speak about their business operations in their own parlance. Two interviews were conducted in Spanish (the native and more fluent language of both of these interviewees) with the rest in English (a native language for the three other interviewers). Interviewees were first asked about the duration of their experience in the food cart business, their motivations for starting a business and the tenure at their current pod. Once the conversation was flowing, each interviewee was eager to tell their story. So as not to frame the entire interview around local food and avoid leading questions, I directly asked interviewees how they source their food supplies only if the information was not given freely in conversation (two of the five readily gave the information without prompting). For the two interviewees that discussed their sourcing more openly, the concept of local or regional was already a part of their habitus as cart owners. Both of these two owners estimated the average percentage of local food used out of their entire food supply. One owner (serving

\footnotetext{
${ }^{23}$ Early in the interviewee recruiting process, one cart owner actually shut down their business and sold their cart in a matter of weeks after agreeing to interview when business slowed down. I later discovered via a response to a customer comment on the cart's Facebook page that business was so slow that they could no longer afford to operate and had to shut down for good. A different cart operator from Africa at an East Portland pod agreed to speak with me, but asked if her husband could help her translate as she was not confident in her English abilities. I arrived at time we discussed, but the husband did not want to talk. There was certainly a language barrier for him as well, but he did not wish to participate in the dialogue. He even stood in front of his wife as I attempted to engage him, speaking on her behalf.
} 
fusion cuisine) broke down their local sourcing even further, listing separate percentages for the following categories: meats, produce, grains, dry goods, and non-food supplies.

Interviews were transcribed and coded for major research themes. Participants were coded (e.g. "FCO1") to remain as anonymous and as gender-neutral as possible. ${ }^{24}$ Hand-written field notes were kept as both a backup for main points of the interviews as well as a means of documenting site observations (e.g. types of customers, distinct atmospheric qualities). This produced five unique accounts that reflected the style and thought patterns of each interviewee. Some would discuss certain topics at length, such as the difference between flavors and sources in Latin American countries or how catering large festivals out of state was completely different than operating an essentially stationary cart in an East Portland parking lot. I had to carefully direct a few interviews that strayed too far off on topics; some interviewees even caught themselves in the middle of a rant on personal pet peeves (e.g. "trendy" diets like gluten-free and vegan). As such, the interviews ranged from around twenty-five to sixty-five minutes. Interviews were concluded when sufficient dialogue around the key topics (motivations for serving food, what is emphasized in promoting their products/business, how their food is sourced, and what they think of Portland's reputation as a food and sustainability capital) had taken place.

\footnotetext{
${ }^{24}$ One interviewee elected not to remain anonymous. 34
} 


\section{Chapter 5: What the Carts Say - A Material Inventory of Food Cart Pods in \\ Eastern Portland}

This chapter presents the inventory of cart materials obtained during site visits via photos of on-cart signage and menus, as well as online marketing through the websites and social media profiles of individual carts and additional sites hosted by pod owners for descriptions of carts and menus (e.g. Foodcartsportland.com, which estimates 2 million site hits in 2012). As outlined in the previous chapter, the collection of materials was reviewed for content related to themes of food quality (local, regional, fresh, organic). This information is displayed in Figure 1 and Table 2 below. The pods were numbered from 1-8, starting from the eastern most pods and ending with the pod closest to the Willamette River. 


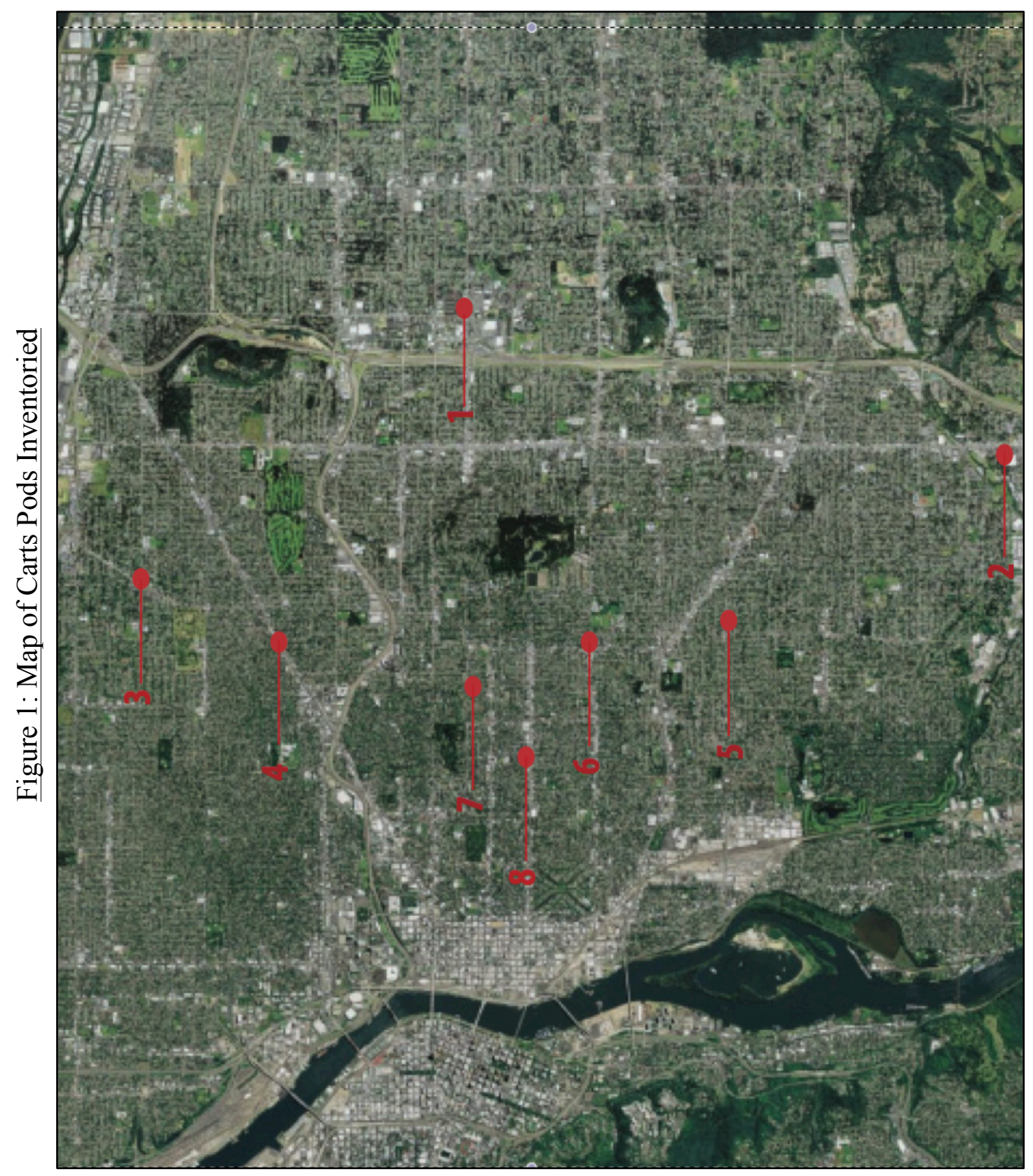


Table 2: Inventory of Food Cart Marketing Materials in Eastern Portland

\begin{tabular}{|c|c|c|c|c|c|c|c|}
\hline $\begin{array}{c}\text { Pod ID } \\
\text { (Figure 1) }\end{array}$ & Pod Name & $\begin{array}{l}\text { \# Of } \\
\text { Carts }\end{array}$ & Fresh & Local & Organic & Seasonal & $\begin{array}{l}\text { Ethnic } \\
\text { Cuisine }\end{array}$ \\
\hline 1 & AlaCarts & 7 & 1 & 0 & 0 & 0 & 6 \\
\hline 2 & Cartlandia & 21 & 7 & 0 & 0 & 0 & 10 \\
\hline 3 & 5 Ways & 4 & 2 & 2 & 2 & 1 & 3 \\
\hline 4 & $\begin{array}{l}\text { Rose City } \\
\text { Food Park }\end{array}$ & 8 & 0 & 1 & 1 & 1 & 5 \\
\hline 5 & $\begin{array}{c}\text { Carts on } \\
\text { Foster }\end{array}$ & 14 & 4 & 3 & 3 & 1 & 7 \\
\hline 6 & $\begin{array}{c}\text { A la Carts } \\
\text { Food } \\
\text { Pavilion }\end{array}$ & 12 & 4 & 2 & 0 & 0 & 8 \\
\hline 7 & $\begin{array}{c}\text { Good Food } \\
\text { Here }\end{array}$ & 12 & 3 & 3 & 0 & 1 & 3 \\
\hline 8 & No name & 4 & 2 & 1 & 0 & 0 & 2 \\
\hline \multicolumn{2}{|c|}{ Totals } & 81 & 23 & 12 & 6 & 4 & 44 \\
\hline
\end{tabular}

The type of materials through which carts owners communicate their culinary offerings ranges from hand-made menus to regularly updated menus and specials available online. ${ }^{25}$ The majority of carts inventoried in Eastern Portland had some degree of social media presence. Foodcartsportland.com, a popular repository of Portland food cart information, posts some menus and promotions, but information for some carts and pods can be out of date given the sheer volume of carts, movement between cart pods,

\footnotetext{
${ }^{25}$ See Appendix B for a sample of materials collected.
} 
and carts closing down. Approximately 17 percent of carts maintained their own website at the time of the inventory. Menus were posted online for 21 of the 81 carts inventoried, either through individual websites or social media, pod websites or foodcartsportland.com. Almost half of the carts (38) had their own Facebook page at the time of writing.

Over half of the carts inventoried in East Portland served "ethnic" cuisine, as defined as food types from ethnic cultures (e.g. Thai, Mexican, El Salvadoran, Guamanian) or types of cuisine from US regions outside of the Pacific Northwest food (e.g. "southern BBQ"). ${ }^{26}$ Product freshness was the most frequent quality-related advertising priority, with just under 30 percent of the carts claiming some type of "fresh" cuisine. Only 15 percent of carts surveyed advertised local ingredients, and organic was present in less than 0.1 percent of materials. The carts that did advertise local or regional products were mostly located in the western part of the area sampled (pods \# 3-7) with one cart represented from two easternmost pods (pod \# 2). Of these pods, pod 3 (the farthest West) had by far the largest proportion of materials related to local and organic food.

Certain pod owners maintained websites and social media profiles for their pods, sharing specials and highlighting carts, and market their collection of carts as social destinations with luxurious accouterments and on-site entertainment. Of the 8 pods, 6 have a Facebook page and 4 have a dedicated pod website. There is a range of online involvement by pod owners in this sample, and some pods were only promoted by on-site

\footnotetext{
${ }^{26}$ I defined a cart as "ethnic" if it advertised something outside of this region. For example, I considered "southern BBQ" to be a type of ethnic cuisine if the owners were advertising their southern heritage. Carts that offered "BBQ" without any such exotic claims were not considered ethnic. These cases were few in number.
} 
signs and listed on foodcartsportland.com. For example, pod \# 3 (at NE $60^{\text {th }} \&$ Cully) did not have a website or any social media pages as a pod, and none of the four carts had an online menu at the time of this writing. In terms of materials at the pod level, only one of the eight pods inventoried exhibited strong claims for sourcing local food based on the materials assessed from individual carts. This pod is the newest of the eight sampled (approximately 1.5 years of operation at the time of writing), and claims to be "Portland's first and only food cart pod to be $100 \%$ compostable and recyclable" and includes a market serving local and regional food on the premises (Rose City Food Park, 2014). The street-facing banner includes the tag "From the Farm to the Table" under the name. Signs inside the pod inform customers that packaging materials used at the food cart are compostable and provide a diagram of what is compostable and recyclable. [One sign even implicated such knowledge among the food cart owners at this pod: "Still not sure where it goes? Feel free to ask any cart operator for help." $\left.{ }^{27}\right]$ Many carts at this pod marketed more themes related to food sustainability than most all other carts inventoried at the other seven pod locations. One cart owner proclaimed near the top of their menu: "I buy local fresh products and support local businesses." Another menu read: "We only use local, Pacific Northwest proteins." Another cart advertised "organic local" meat products on their banners. This pod is also in a neighborhood that is experiencing new redevelopment. Additionally, this pod had local farmers market on the premises.

\footnotetext{
${ }^{27}$ See Appendix B.
} 


\subsection{Field Observations from Pods in Eastern Portland}

This section will describe some of my observations in of these two food cart pods, which date back over the course of two years when I first became interested in exploring the differentiation in food cart practices as a potential topic of research.

The first pod I began frequenting stood out from my first site visit. Located near a strip mall in East Portland between two major thoroughfares, this food cart pod very much remains a functioning parking lot for customers. In contrast to downtown pods where carts almost always outnumber parking spaces (e.g. SW $10 \&$ Washington, SW $4^{\text {th }}$ $\&$ College), anywhere from ten to fifteen cars can fit on the lot. Indeed, I never observed an empty lot devoid of vehicles in my frequent site visits, which varied in the time of day from early lunch to late dinner. Judging by the traffic patterns, most of the vehicles belonged to customers. This pod has a sizeable outdoor tent (which an interviewee later told me was paid for collectively by the cart owners with the consent of the lot owner) but no fixed barriers to stop cars from parking right up against the seating areas.

This is a completely "ethnic" pod, absent a single owner or operator that is White. Every owner spoke a native language other than English; two of the owners spoke very little English. After patronizing each cart at least once and asking casual questions, I learned that all but one of the carts that normally operate at this pod (which fluctuated from five to eight carts during my year and half of observations) are unique food service venues in the sense that they do not have any "sister" carts or restaurants. The exception is a Salvadoran cart, which is an extension of a restaurant located further east on $142^{\text {nd }}$ Avenue. The owner of this particular cart is not around often. None of the carts displayed 
offerings of "fresh" or "local" ingredients on menus or cart exteriors. The pod as a collective does not have an online presence, and a food cart owner I later interviewed reported seeing the lot owner a total of three times in over year at the location. This pod has no collective social media presence, which was also the case for each individual cart at time of my inventory. ${ }^{28}$

The second pod I began frequenting during this study differs considerably from the other both aesthetically and operationally. The other East Portland pod was located at a busy intersection of two busy tributaries, while this pod faced busy $82^{\text {nd }}$ Avenue in a mostly residential surrounding area. This pod has nearly three times the amount of carts in what feels like an even larger space per cart, to the extent that there are "back lot" carts that you cannot see from the road that place signs to attract customer already in pod to their recessed locations. The pod is home to a spacious, screened in lounge area complete with a beer garden and a massive television that broadcasts sports games and popular TV shows. There are many cart owners at this pod that are immigrants, but due to the sheer number of carts it is also home to a gourmet lobster cart, two different varieties of BBQ, a "classic diner" with "American style food" served in enormous portions, and even the brick n' mortar tourist icon Voodoo Donuts. In contrast to the other East Portland pod I observed, one third of the carts at this pod advertised "fresh" ingredients in their food, although none displayed any claims about the type of sourcing.

Perhaps due to the sheer size of this parking lot, the customer traffic seemed fairly sparse during most of my visits (which took place at various times of day on weekdays and weekend) even though the pod offers ample parking, covered seating, and beer inside

\footnotetext{
${ }^{28}$ Internet searches for these carts will yield results from Yelp and other sites hosting customer reviews.
} 
of the gates. There was a fair amount of turnover in carts at this pod in the over two years of observation, especially among carts that are visually blocked from the roadside entrance. One of the cart owners that I interviewed there told me that their cart had already moved from the very back of lot to the middle-back after just a few months of tenancy. The owners of the lot have a very active social media presence that promotes individual cart, including new arrivals, limited-time deals, special menu items and closures. During a period of sidewalk construction, for example, the pod flooded social media outlets with progress updates, photos, and reminders to customers to use the alternate entrance. In addition, the pod has its own website with advertisements for each cart, including menu items. ${ }^{29}$

I included these vignettes on the two pods to demonstrate their differences with respect to downtown and "inner ring carts" - some of the larger-sized carts at this pod would never fit into a downtown pod space - but also to illustrate variations among the two sites within the Eastern Portland sample area.

\footnotetext{
${ }^{29}$ The pod's website did claim that one of the carts sources their food locally, although the individual cart's own website said nothing of local or regional sourcing (only "fresh" ingredients). Naturally, pod websites and other resources often lag behind the changes in actual cart menus due to supply constraints.
} 


\section{Chapter 6: Ethnic Cuisine \& Local Food: Interviews with Food Cart Owners in}

\section{Eastern Portland}

"Interviews are specific discursive space, and the interview questions as well as the interviewer's participation are a crucial part of the data... Interview data are analyzed both for their local organization as interviews and as a specimen of cultural knowledge, logic, and meaning making” (Nikander, 2012: 410).

\subsection{Interviews as Discourse Data}

Interviews were analyzed discursively, focusing on how each interviewee gave an account of their identities as both food cart owners and as members of ethnic or minority communities and how they "orient to, mobilize, (re)define, contest, and manage" key themes and topics and how they use "identity as a discursive resource" in giving accounts of themselves (Nikander, 2012: 404). Though I made a concerted effort to guide the conversation rather than approach it as pure extraction of objective information, I was cognizant of aspects of co-creation in each specific interview account. As such, this represented a "specimen of cultural knowledge" (ibid: 410) in a discursive space that firmly implicated myself as the researcher in this synthesized accounting process (Butler, 2001). I will now give a brief account of these co-created conversations and then assess the larger themes that emerged from the entirety of the interviews conducted.

The first interview took place in mid-afternoon at a pod in East Portland. I had set up a time with the owner (FCO1) during a previous visit where they readily agreed to talk during their daily lull in customer traffic. We sat right outside of the customer window of the cart, with FCO1 in earshot of their spouse and the other cart employee that were handling operations while we talked. FCO1 is foreign-born, but has spent the last twenty- 
two years in Portland. A former restaurant operator who obtained their current food cart from an uncle, FCO1 remarked, "owning a food cart is easy" compared to a restaurant. It's a more relaxed arrangement where you can set your own hours, and it's pretty obvious what you need to do to pay your bills. I asked about advertising, to which FCO1 replied that they used to advertise in a nearby hotel's magazine and that the main point of their advertising was "fresh, handmade food that is not heavily processed." They then lamented about a recent loss of business-class customers due to company closures in the area and in the same breath remarked that takes time to cultivate a consistent customer base. Taking the comment about "fresh and handmade" as a conversational segue, I asked about producing food supplies. FCO1 replied that they stock their three fridges (vegetables, meat, and other) two to three times per week consistently, with Cash $\&$ Carry as the main source. FCO1 said it costs more for "foreign food" (components of their ethnic cuisine). I asked about local food and they responded that they used to go to a nearby farmers market in East Portland, but that stopped because there is only a threemonth window (June to August) where products used the cart are cheaper. Prices are doubled for tomatoes, for example, if you go during end-of-season. They then told me that they don't really care about local ingredients primarily. They are more focused on non-processed foods, and local is one option to attain this perceived quality.

FCO2 is a US-born minority who had moved to Portland within the past year to add their brand of Southern cooking to the city's thriving mobile food scene. FCO2 agreed to meet me at their cart in East Portland during the middle of a weekday. This was also a pre-arranged meeting from a previous visit tot the cart. I asked FCO2 to talk about 
how they chose this cart and what it's like to do business as a recent newcomer to Portland. With over four years of cooking large quantities of food to serve at big festivals, this was the first "stationary" roadside gig for FCO2. This change of pace was a common theme of the interview. FCO2 chose this pod to accommodate their large trailer, which includes a smoker, a fridge and a steam table (all of which have reportedly low energy costs). Based on their research when selecting a pod location, downtown cart spaces were vastly more expensive to rent, especially for large trailers. Marketing their products has been most successful through word-of-mouth. FCO2 also uses social media platforms to advertise specials, which have been a big part of getting more business to the cart. FCO2 told me that they source most of their products from Cash \& Carry or Costco (Fred Meyer or Safeway in a pinch) depending on which had the best sales. There would be no benefit to purchasing local products, they told me, based upon the customers in the current location because, "the population doesn't demand it." This owner briefly explored partnering with a local farmer, but that this a two-tiered menu (local and non-local) that would probably just be used for catering special events, unless they were to move to a different area of town. They again lamented that they wished their clients had money.

FCO3 was the only interview conducted off-site. We corresponded via email (also unique) and met a local coffee shop. A younger former employee of a local Asian restaurant, FCO3 told me about "shit breaking" in their cart and how, after several months of downtime (and lost profit), the cart enterprise was saved through a Kickstarter campaign that exceed their fundraising goal by a substantial amount. Born and raised in Portland in the same neighborhood where the cart sits, the modus operandi for FCO3 are 
to offer unique fusions of ethnic cuisines that "surprise people." They said that money isn't really a motivating factor and that they wish they could "impeccably source" everything from local products. Even on somewhat of a budget (and self-ascribed "poor" business acumen), FCO3 quickly rattled off percentages of locally sourced food by category in descending order of locality: meat (nearly 100\%), produce (around 50\%), pantry items (around $20 \%$ ), and spices ( $0 \%$, due to their "exotic" origins). FCO3 obtains these supplies (estimated at around $30-40 \%$ of local overall) from Krueger's farmers market (where she gets a personal discount), Trader Joes (a relatively new find), but also Asian supermarket Fubonn (for spices and aromatics) and Cash N Carry (for some pantry and most non-food items). This cart owner displayed the most knowledge about local sourcing out of all interviewees and spoke the most openly about food politics (a "love/hate" relationship with Fubonn over recent labor disputes). The fusion-oriented menu of their cart means that $100 \%$ local food sourcing is not possible, they said, but it is still a goal and a means of differentiating their menu to attract new customers. Given the acumen and commitment, I was surprised to hear FCO3 express a feeling of being "a bit outside" local AFNs in the Portland area. FCO3 then described their pod location, which emerged in a kind of DIY fashion due to FCO3's existing relationship with the lot owner (a family friend and former colleague).

FCO4 is a female-owned business, and the second in my sample that is operated by a couple. This interview finally took place after a few emergency no-shows and closures due to bad weather. FCO4 stated their motivation for starting a food cart (after having high-profile culinary jobs working for the department of health in their home 
country) was simply to "make something that is mine." FCO4 spent several minutes discussing cultural differences between cuisines in the home and neighboring countries of the particular ethnic food they offer. Most of the ingredients used in the cart are common to the Pacific Northwest, but certain spices and peppers must be bought at stores that import them from abroad. When I probed this point further I was informed that people from their home country often shop at the same stores, but that these stores are more regionally ethnic (e.g. multiple nations). As such, when FCO4 described how people from the local area that share their culture heritage are some of the most consistent customers to their East Portland cart, they again used regional rather than national definitions of cultural identity. This cart uses supplies mostly from Cash N Carry and Restaurant Depot (an estimated 80 percent of all supplies) as farmers markets are neither economically viable for business operations nor open long enough for it to impact sourcing habits. FCO4 often substitutes food inputs like vegetables with regional variations from the Pacific Northwest. No matter where the products come from, FCO4 told me that the overarching priority is making a place for themselves and offering the best quality food at the lowest price. Local is but one option for product quality, but not one that is particularly resonant with their every culinary practices.

FCO5 is from a small island nation and is one of the sole commercial food providers of this particular ethnic variety in the greater Portland area. FCO5's modus operandi for operating a food cart is a pretty straightforward blend of their home cooking and regional sourcing of Pacific Northwest products. A quote about their commitment to fresh and local food is on display on their cart and menus. FCO5 was the sole worker at 
their cart at the time of the interview. FCO5 told me that they initially wanted to open a restaurant, but that there was no outlet for their particular ethnic cuisine. Having been stationed at three different pod locations throughout the city, FCO5 remarked how surprised they were at the amount of people from their same homeland living in Portland. Running their cart was thus a means to connect with additional people of similar national origin. Consistent with nearly all other interviewees, word-of-mouth had been the bestreported means of marketing. Moving pods gave FCO5 an interesting perspective on the most recent pod (approximately 1.5 years in existence at the time of the interview) that is very conscious of food waste and contains other carts that prioritize locally sourced food supplies. FCO5 told me that they shop for local supplies even in box-box stores like Fred Meyer, but that they prefer farmers' markets when the cost difference is not too high. In addition, some of the spices used to prepare the ethnic cuisine are only available at stores like Fubonn, which means that an idea of $100 \%$ is not possible to achieve while maintaining the flavor of the ethnic cuisine. For FCO5, local is defined as the Pacific Northwest region (OR, WA and northern CA). When asked if they had additional comments, they described a "pet-peeve" of dietary fads like vegan and gluten-free, which are often a used as marketing "gimmicks" and trendy repositions of foods (e.g. corn tortillas are naturally gluten free). FCO5 vastly prefers the family-oriented environment of their pod in the Central Northwest Neighborhood district to downtown, which lacks restrooms and is generally a more cutthroat environment in which to operate a food cart. I present these personal narratives as means, however partial, of understanding the everyday practices of cart owners from their own perspectives and in their own terms. In 
the following chapter, I incorporate these perspectives along with the entirety of the data collected to construct and analyze the full situation of this inquiry. 


\section{Chapter 7: A Situational Analysis of Ethnic Food Cart Supplies in Eastern Portland}

Using Clarke's (2005) situational analysis framework, this chapter synthesizes the entirety of the data collected to construct and interpret the situation at hand: local food sourcing and ethnic food carts in Eastern Portland. Situational analysis is an appropriate tool for the under-investigated area of this study as it employs a range of theories from qualitative analysis (grounded theory, symbolic interactionism, social worlds/arenas, discourse theory) to collect and analyze various types of qualitative data (existing narratives, qualitative data generated by the researcher) with the goal of understanding human and non-human actors and articulating the positions taken and not taken within the situation.

I explore how differences in the common sense and everyday practice (or habitus) of food cart owners serving ethnic food in East Portland reflect varying positions regarding the desirability and feasibility of buying local or regional food supplies. These food cart owners, the majority of whom are immigrant or minority entrepreneurs, mobilize aspects of the established notions, or doxa, common in Portland's alternative food movements (e.g. buying local; as reviewed in Chapter 3) to varying degrees based on factors that include their neighborhood customer bases, the availability of ingredients for their ethnic cuisines, and their sources of information and overall cultural literacy of Portland local alternative food networks (AFNs). I relate their positions to findings from the material inventory of cart pods and well as the two major narratives (or discourses) reviewed in chapter three (the Portland food cart phenomenon and local AFNs in the greater Portland area). The two popular narratives represent fields or arenas of collective 
action that are constantly being shaped by human actors (e.g., food cart owners, pod/lot owners) while also being impacted and potentially constrained by human (e.g. neighborhood customer bases) and non-human (e.g. seasonal changes in local food availability; type of ingredients in the ethnic cuisine) elements.

\subsection{Eastern Portland Carts \& Urban Location}

The area of Eastern Portland ${ }^{30}$ that I have outlined as the sample boundary for the situation at provides a markedly different setting for examining the city's food cart phenomenon due to spatial and demographic characteristics that distinguish this area from downtown and "inner-ring" neighborhoods. The sample areas used in existing studies on the Portland food cart phenomenon to date have focused on pod locations in the more central city areas and the more western areas of Portland $(\mathrm{NW}, \mathrm{SW}, \mathrm{N}$, inner $\mathrm{NE}$, and inner SE). These areas have different histories of urban development compared to the area of Eastern Portland outlined in this study, which is currently a destination for Portland's growing immigrant and minority populations. ${ }^{31}$ These existing studies on the Portland food cart phenomenon included just one site that overlaps with this study (at NE $60^{\text {th }} \&$ Cully Boulevard). Aside from this pod in the Cully neighborhood, the pods from previous studies are all located in more western areas of the city with relatively higher sidewalk densities that denote a more connected or pedestrian-friendly surrounding environment. Figure 2 uses sidewalk data from 2010 to display the relative density and connectivity of these areas as compared to eastern parts of the city.

\footnotetext{
${ }^{30}$ Eastern Portland is a combination of three of the seven District Coalitions -the Central Northeast Neighbors (CNN), Southeast Uplift Neighborhood Coalition (SEUL), and East Portland Neighborhood Office (EPNO) -and is home to approximately 60 percent of total city's population (City of Portland, 2014c) and 68 percent of its foreign-born residents (City of Portland, 2014c). (Appendix A for population maps by District Coalition).

${ }^{31}$ See Chapter 4 and Appendix A.
} 
Figure 2: Map of Sidewalks \& Carts Inventoried in Portland (2010 Data)

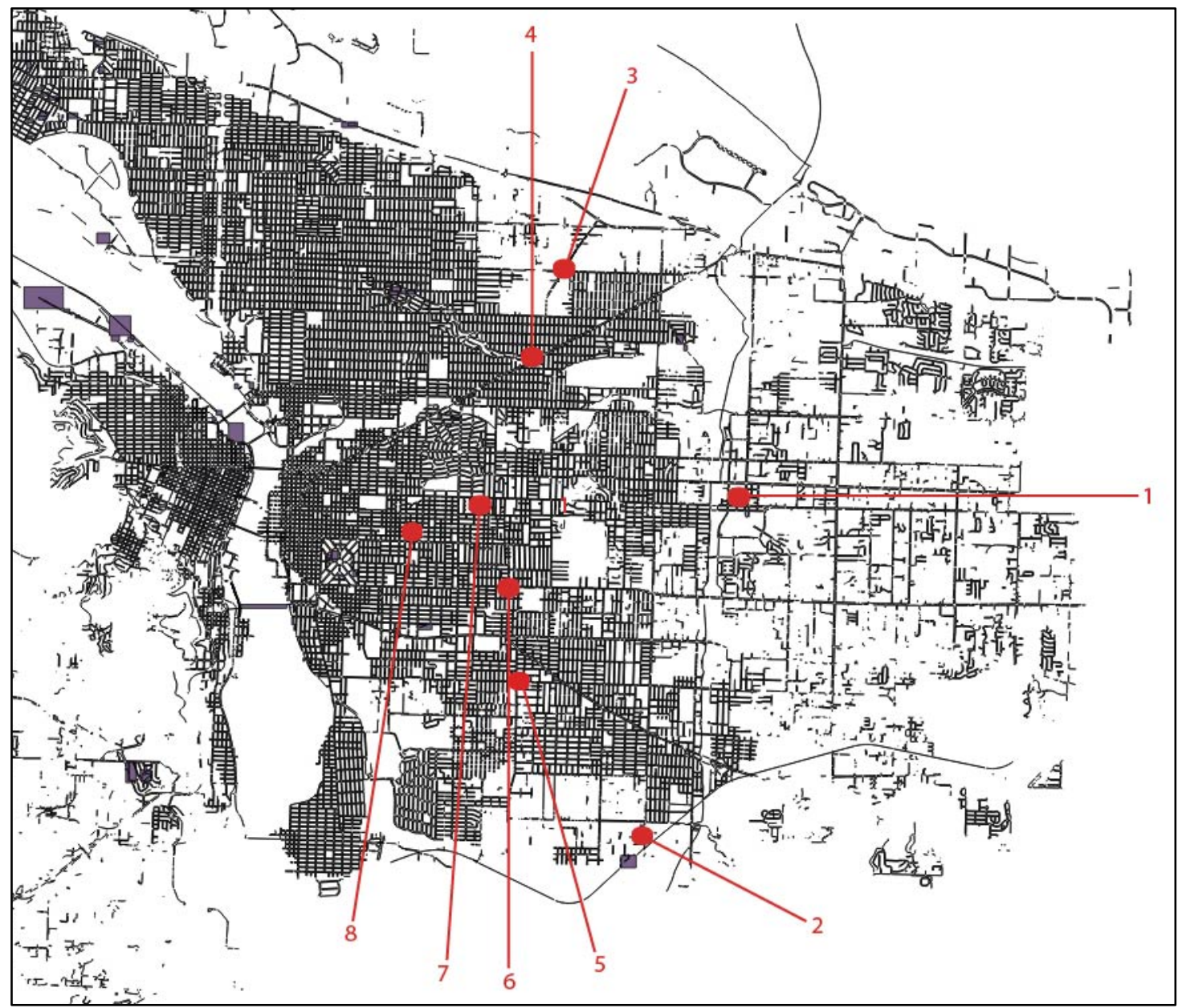

(Data source: Civicapps.org)

As the concentration of the sidewalk lines in Figure 2 indicates, downtown and "inner-ring" neighborhoods are more densely connected than the rest of the city. This is to be expected given the city's focus on walkability and other lifestyle-oriented amenities in downtown and nearby commercial areas (City of Portland, 2012). Figure 2 also displays variation in sidewalk density for the pods within the Eastern Portland area. Within Eastern Portland, the pods located between NE Freemont and SE Division (north to south) and $32^{\text {nd }}$ Ave. and $60^{\text {th }}$ Ave. (west to east) are all in areas with relatively high 
sidewalk density. This accounts for 5 of the 8 pods in the Eastern Portland area. Moving east, there is still a relatively high sidewalk density around each until you reach $82^{\text {nd }}$ Avenue, with the exception of the car-friendly pod in the Cully neighborhood pod (pod 3 in this study) that is surrounded by a relative lack of sidewalks in three directions (the name of this pod, 5Ways, refers to the intersection at which it is located). Located right off of $82^{\text {nd }}$ Avenue, the southernmost pod in this area is also the largest pod by total lot area and number of carts. Although it's at a more peripheral location within the city, this pod is billed as a bike-friendly "super pod" that advertises its proximity to the Springwater Corridor bike trail (an appeal to Portland's biking sensibilities) but also has ample parking for cars via $82^{\text {nd }}$ Ave. The easternmost pod in this study (pod \#1) is in an immediate area with relatively no sidewalk connectivity, between a freeway and a collection of strip malls. This car-friendly pod has no active advertising at the pod level beyond two on-site signs with the pod names and the individual cart names on the back of carts that face oncoming traffic.

\subsection{Negotiating Cultural \& Culinary Identities in Eastern Portland's Street-Level}

\section{Networks}

In Eastern Portland, an assemblage of human and non-human elements have coalesced into variegated sites of quasi-mobile food marketplaces that offer a range of ethnic eating experiences to customers, with varying sourcing practices. There are no extreme locavore carts in this area of the city (such as the now-defunct "100 miles PDX" cart, previously located on NE $21^{\text {st }} \&$ Alberta, that obtained "99 percent of its foods from local farmers" as a rule), although some cart owners operating in Eastern Portland at the 
time of this publication wouldn't mind using such "impeccable" sourcing practices under different circumstances (100 Miles PDX, 2011). Additionally, food cart sustainability innovations like GO Box's reusable food containers were only linked to vendors in the CBD at the time of the inventory. ${ }^{32}$

Within the street-level networks in Eastern Portland, foreign-born and minority food cart owners serve their ethnic cuisines to fellow immigrant and ethnic populations while also attempting to cultivate a customer base from the rest of Portland's voracious foodie community. Operating food cart is a relatively low-cost option for immigrant and minority groups seeking self-employment ("algo propio" in Spanish) within a larger food service sector that often relegates ethnic minorities to non-ownership positions in the back of the kitchen or as day laborers (Allen, 2010; 301). In serving ethnic food, these cart owners are crafting cultural messages that blend their respective places of origin with appeals to the existing cultural images of the historically White city of Portland known for its craft economies, locavore ethics and other sustainable sensibilities with an ostensible focus on building communities. Homegrown actors are also shaping the ethnic food cart scene, exemplified by the young, White Portland native with culinary training and experience at an Asian restaurant now serving ethnic fusion cuisine at her cart, with the eventual goal of opening a restaurant based on their unique brand of culinary fusion.

\subsection{Food Supply Options in the Situation}

The range of food supply options for food supplies for cart owners serving ethnic food in Eastern Portland ranges by the size (big-box to small market), targeted audience (wholesale or general consumers), type of quality advertised (low-cost, high-end), and the

\footnotetext{
${ }^{32}$ Source: https://www.goboxpdx.com/find-gobox-vendors/.
} 
origin of their food supplies (international, regional). There are wholesale suppliers that specifically target independent foodservice operators with quality, low-cost items, such as Cash \& Carry (six locations within the Portland metro area) and Restaurant Depot (one location in Portland). Big-box grocers like Costco (six locations in the Portland metro area), Safeway (16 locations in Portland), and Fred Meyer (12 locations in Portland) offer additional options on bulk items (Costco is also a wholesaler) as well as a wide variety of meat, dairy, grain, and produce options from various points of origin. Higher-end grocers that specialized in organic, local and otherwise sustainable food supplies include the Texas-based Whole Foods (four stores in the city), and the smaller Northwest chains of New Seasons Market (seven city locations) and Zupan's Markets (four locations in the Portland metro area) that all claim some degree of support for local growers and their products. There are also local food cooperatives that have grocery store fronts for members and non-members, including People's Food Co-op (SE $21^{\text {st }}$ Ave. \& Tibbetts), Know Thy Food (SE Milwaukie Ave. @ 12 $2^{\text {th }}$ Ave.), the Alberta Cooperative Grocery (NE Alberta $\& 15^{\text {th }}$ Ave.), and Food Front Cooperative Grocery (NW $23^{\text {rd }} \&$ Thurman). Similarly, there are approximately 14 farmers market stands operating within the city limits, with an additional 24 in the surrounding metro area (EOC, 2014). In terms of specifically ethnic food supplies, the options range from box-box ethnic groceries like Fubonn ("The Largest Asian Shopping Center in Oregon" located at SE $82^{\text {nd }}$ Ave.) and Hong Phat (two locations on SE $82^{\text {nd }}$ Ave. and NE Prescott St.), to smaller and formal groupings of ethnic stories. Owners from Latin America often shop at smaller stores ("tiendas" in Spanish) that are either branded by a single one nationality 
(e.g., "Mexican," the most popular), a group of countries (e.g., "Central American") or

Latin America as a whole. ${ }^{33}$ In general, the Eastern Portland study area has more big-box grocers and ethnic food outlets than high-end local or organic specialty grocers. ${ }^{34}$

\subsection{Food Supply Routines in the Situation}

The purchasing of food supplies is a daily concern for cart owners serving ethnic food and is typically the most significant portion of operating costs aside from rent. These sourcing decisions are routinized on a weekly or even daily basis based on variables like product cost, availability of ingredients by season and ethnic origin, and customer demand for menu items. The mix of food cart owners and food supply options in this situation results in a range of cross-cultural transactions within both the "conventional" and "alternative" food networks in the Portland metro area to supply ethnic-specific (e.g., bok choi, nopales) and more common (e.g., meat) ingredients. Cart owners serving ethnic food can purchase most of their ethnic ingredients from stores that are grouped into larger ethnic categories, like tiendas (Mexican or Central American in name) or pan-Asian grocers. Yet, the cart owners interviewed stated the vast majority (around 80 percent) of the ingredients for their ethnic food items could technically be grown in the Pacific Northwest. In terms of basic food supplies (meat, grains, dairy), wholesale food distributors Cash \& Carry and Restaurant Depot were the two most frequented food supply destinations mentioned by all food cart owners interviewed in this study. Asian grocers Fubonn and Hong Phat were the most popular sources for imported spices, sauces and exotic ingredients that aren't available from foodservice wholesalers or

\footnotetext{
${ }^{33}$ A Yellow Pages search at the time of writing yielded 32 results for the category "Mexican \& Latin American" grocery stores in the Portland metro area (Yellowpages.com, 2014).

${ }^{34}$ Based on locations for Whole Foods, Zupan's, and New Seasons, there are no high-end grocers in the Portland city limits east of $41^{\text {st }}$ Avenue.
} 
local producers. For most cart owners serving ethnic food in Eastern Portland, farmers markets are seasonal options at best with a short purchasing window that is subject to prince constraints and often continent upon personal relationships between cart owners and market operators. Big-box grocers like Safeway and Fred Meyer are less frequent options based on last-minute restocking needs or special sales on particular food items.

The sourcing routines of owners reflect their individual positions, or habitus, by which they make claims to "ethnic" or "ethnic fusion" cuisine. The individual's habitus is a fluid construct that is structured by the norms of their ethnic communities of origin as well as experiences as immigrants to Portland. Their habitus is also in a process of structuring that is being constantly shaped the modus operandi of their cart businesses, the effectiveness of their branding efforts, the type of customers that frequent their carts, and their access to and perspectives on the local AFNs in Portland. The cart owner serving food from their native Pacific Islander cuisine with a Portland locavore spin is creating a new dispositional form and culinary offering of a hybrid cuisine that is simultaneously exotic and local in both form and function. Firmly embracing the locavore ethnic as part of their brand, this cart owner is ideally located in the pod that was most firmly committed to local food and food sustainability of all the pods inventoried in Eastern Portland. This cart owner is a relative outlier in this situation, where the less than 15 percent of all carts inventoried employ the origin of their food products as part of their brand in marketing strategies (Table 1). This particular cart also benefits from having no direct competition for its ethnic brand: it's the only cart of its ethnic ilk in the city. In contrast, a recent transplant to Portland serving family recipes from the Southern U.S. 
would ideally prefer to use more local products, but is constrained by the perceived purchasing power of the customers that frequent their pod on $82^{\text {nd }}$ Ave. As such, the cache of consuming local ingredients is not universally valued throughout city, or within Eastern Portland itself.

\subsection{Pod-Level Distinctions}

Grouped into pods with a range of 4 to 21 carts, these cart owners also collaborate in creating pan-ethnic consortiums at their pod locations. Most owners exchange food, business knowledge and cooperate to provide amenities like covered seating in the absence of an active pod owner. The ethnic food cart owners in pods in Eastern Portland are seeking to distinguish their culinary brand from others at their same pod location but also within the larger field of the city's mobile food phenomenon. In terms of food quality claims, local sourcing is not much of a priority or means of distinction for carts in Eastern Portland pod locations. The cart owners inventoried were twice likely to advertise "fresh" as they are "local" in distinguishing quality of their food (though both were in relatively small proportions with respect to the larger inventory). To a certain degree, this can be attributed to differences in cultural literacy about the locavore movement in Portland. Though generally regarded as positive, the sources of information that the owners interviewed use to obtain information about local sourcing options varied. Owners of Latin American origin obtained general information in their native Spanish (e.g. from the television network Canal 2; consulates representing their home country). Other owners (all native speakers of English) actively engaged with area farmers and grocers selling local and regional food to build personal relationships. 
Just as individual cart owners distinguish their carts in a variety of manners, pods themselves compete as destinations. Some pod owners widely promote their pods as social scenes by calling attention to their collection of cart owners and their on-site amenities. The less dense areas of Eastern Portland make large beer gardens, brick-andmortar restrooms, and family play areas an economically feasible option for pod owners compared with the tight spaces and lack of amenities (or less desirable amenities, in the example of port-o-potties) available in more dense central areas of the city. For other pods in East Portland, pod advertisement does not go beyond a large sign at the corner of a busy intersection, and cart owners at these pods must rely on their own resources or collaboration with other cart owners to provide customer amenities. The allure of covered, heated seating during Portland winters cannot be understated. Customers who frequent the more peripheral pods of Eastern Portland (especially east of $60^{\text {th }}$ Ave.) do not have the luxury of retreating into an office building or a nearby storefront. With anywhere from 500 to 700 carts at any given time throughout the city, convenience and amenities become an important means of differentiation for carts and cart pods.

\subsection{Regulations in the East Portland Ethnic Food Cart Situation}

Consistent with conclusions from previous studies on Portland food carts, the situation of ethnic food carts in Eastern Portland has been fostered by a largely selfpolicing regulatory environment amenable to independent action with regards to food supply sourcing and on-site amenities. Outside of permitting and bi-annual inspections, cart owners in Eastern Portland are acting largely independent of regulatory bodies that largely treat their carts as low-volume restaurants. One cart owner in a peripheral pod 
stated that they only see regulatory personnel from the county health department twice a year during health inspections. They stated that, in terms of food service establishments, carts might be more accountable to daily customers in terms of health, as the condensed design of food carts makes an unkempt operation more obvious to the consumer compared to a traditional brick-and-mortar restaurant with a more secluded kitchen. Due to a liberal interpretation of the word "mobile," cart and pod owners are also able to construct various amenities to appeal to customers as comfortable social destinations.

\subsection{Situational Definitions of Local}

As would be expected, there were differing opinions on what exactly makes a particular food ingredient "local" or "regional." The more locavore-oriented cart owners accepted anything in the Pacific Northwest watershed as local or regional. State-wise, most cart owners considered Oregon and Washington as eligible for the local or regional distinction, with some exceptions for products coming from Northern California. For one cart owner, the distinction is simple: whatever is a reasonable distance for shipping supplies to their cart, or about 25 miles. Several cart owners stated that customers can tell the difference between fresh products and those that have traveled long distances, while other owners did not profess the same faith in the discerning abilities of the customers' palates. $^{35}$

\subsection{Relating The Situation to Extant Narratives}

Now I will briefly recapitulate the two main narratives of Portland food carts and the local food movement I am addressing and discuss how this study adds to both

\footnotetext{
${ }^{35}$ One cart owner told me, off the record, that they believe other carts mislead customers by falsely advertising "organic" and "local" ingredients, adding that the consumer has very little ability to assess the veracity of such claims (personal conversation, November 2013).
} 
discourses. These two fields, or arenas of action, are being negotiated and contested by the actors involved and are also overlapping and certainly not mutually exclusive.

The narrative on Portland food carts, which I derived from collecting scholarly publications and popular press, views cart pods as diverse food marketplaces that positively impacting urban areas from a community economic development perspective. Carts are both employment opportunities and lower-cost sites for obtaining culturally specific food for minority and immigrant populations, and pods often reflect the urban characteristics of their surrounding areas (e.g. walk-ups for downtown businesspeople at eating lunch; drive-in pods at major intersections in NE and East Portland). Food cart press often takes the tone of a "foodie guide" for local residents and food tourists, and tends to concentrate on the central business district and "inner-ring" neighborhoods. Cart owners add their voices to the narrative with online and social media interactions. Some lot owners appeal to Portlandia sensibilities and trends when advertising their pods (e.g. craft beer tents to watch the Portland Timbers MLS soccer team; 100\% compostable pods sites with family-friendly amenities).

The narrative on the local/regional AFN includes customers and retail food vendors who consume and purchase local or regional food products from producers at sites that include farmers' markets and grocers. This narrative often focuses on direct-toconsumer relationships, such as residential access to healthy food supplies (e.g., New Seasons and farmers' markets). Direct-to-vendor relationships are essentially limited to prepared food from brick-n-mortar establishments (e.g., Hot Lips Pizza, Burgerville, The Farm Cafe) or large-scale institutions (e.g. Portland State University, XXX). The smaller 
DTV relationships described in this study have significant differences in terms of purchasing power, access to credit, and overall consistency and volume of food purchasing routines.

\subsection{Summary of the Situation}

This situational analysis of the data collected in this inquiry on ethnic food carts and food supply chains can be summarized by the following key observations:

1. Current understanding of the Portland food cart phenomenon is based on studies of carts and pods in the CBD and inner-ring neighborhoods. Areas beyond these locations are home to 68 percent of the foreign-born population at 59 percent of the total population (City of Portland, 2014bc).

2. Eastern Portland pods locations exhibit different features of the built environment compared to downtown and "inner-ring" sites. These differences affect pod design, amenities, and branding. Within EPDX, there is a range of pod types. Pods in less connected areas are more car-oriented, with less amenities and appeals to PDX foodie customers in their advertising. The location of the pod relates to certain amenities and distinct features of each pod. In general, CBD and inner-ring pods serve a lot of walk-up customers from nearby businesses (esp. downtown) or in entertainment districts like Mississippi or Alberta. Cart windows are open to the sidewalk in more of a fast-food style. In Eastern Portland, pods tend to be larger and designed to entice customers to sit and socialize in an enclosed pod, rather than just take food to go. With relatively lower land and rent costs, the bigger lots out east are conducive to amenities like bathrooms and beer gardens are cheaper out east. Conversely, there is often less connectivity for walk-up 
and bike-friendly pods. Within the Eastern Portland subset of pods, there is still considerable variation in design, access, amenities, and branding. The pods located further west have more in common with the "inner-ring" pods (sidewalk facing, near commercial areas like SE Hawthorne) than other pods in Eastern Portland. The two least "trendy" pods in this area in terms of design, amenities, sustainability features like compost bins, and owner involvement, both happen to be in areas with lower sidewalk densities (NE 60th \& Cully; SE 102nd \& Stark). The other peripheral EPDX pod at SE 82nd \& Harney is right next to the Springwater Corridor trail - a key message in the pod's advertising that appeals to the city's bike culture.

3. Ethnic food cart owners in Eastern Portland are serving ethnic experiences for surrounding neighborhood customers, their own ethnic populations, and other groups of foodie customers. These exotic offerings are culinary creoles, as recipes may be adjusted to reflect the growing conditions of the Pacific Northwest. Appeals to customers range from quality, ethnic food that is "fully exotic" to ethnic foods or family recipes that incorporate ingredients grown in the Pacific Northwest. The customers themselves are different: Portlanders of all varieties, including a foreign-born and minority clientele from other ethnicities.

4. Food cart owners serving ethnic food in Eastern Portland are aware of the city's reputation as a "foodie" destination for mobile food, many of the ideas behind the locavore mentality, and the city's general commitment to sustainability (and sustainable market strategies). Many immigrant and minority owners have incorporated these ideals of Portland and the Pacific Northwest (a historically white area) into their culinary 
offerings to varying degrees. In the peripheral pods of Eastern Portland, some cart owners are less concerned with serving food at locavore standards than providing low-cost, quality food to ethnic and minority communities. These owners indicated that they have kept fairly consistent culinary practices with respect to their countries of origin, especially the concepts of "fresh" food and personal standards for clean kitchens that go beyond the requirements of county health regulations.

5. Ethnic food cart owners in Eastern Portland are faced with the practical challenges of obtaining ingredients for ethnic cuisine from Portland area suppliers, often obtaining supplies from "ethnic" supply stores in their neighborhood communities.

6. At the time of inventory, carts in Eastern Portland pods were not advertising many local products to customers. Also, most pods were not advertising aspects of sustainability to customers. Certain pod owners, however, mobilize sustainable market strategies (e.g. compost, bike-friendly) to distinguish their food marketplaces.

7. Cart owners have varying definitions of local, from geographic or ecological (Pacific Northwest, Cascadia) to operational (whatever is close enough to ship the product on a frequent basis).

8. For cart owners in the situation had an overall positive view of local food. The perceived benefits of local sourcing included health (product quality and freshness); community economic solidarity (supporting local/regional growers); food system sustainability (decreasing food miles or distance traveled of ingredients); and marketability (appealing to the Portland locavore customers).

9. Buying local for food cart owners serving ethnic food in Eastern Portland is difficult 
for a number of reasons.

A. Many ingredients are seasonal, as are farmers markets and the prices of their goods.

B. The ingredients may not be grown in the Pacific Northwest at all.

C. Bulk items from big-box stores are often much cheaper.

D. Many carts owners are associating local products with higher costs. Certain cart owners indicated that the customer base for carts at certain pods may not support the higher costs associated with purchasing local products.

I will now discuss the limitations of this study, explore future research directions, and discuss the implications of the study for city and regional food sustainability policy goals. 


\section{Chapter 8: Study Limitations, Implications \& Future Research Directions}

This study provides empirical, practical and theoretical contributions to the topics of mobile food, local and alternative food networks, and increasing cultural diversity and population growth in Portland. Empirically speaking, this study adds in-depth descriptions and analyses to ongoing conversations about the Portland food cart phenomenon and the area's local food movement by focusing on ethnic food carts and foreign-born and minority owners in particular. In addition, it highlights some important spatial differences in how the cultural phenomenon of food carts is constructed and cocreated in what I have defined as Eastern Portland. Exploring the habitus of cart owners serving ethnic food at locations throughout the city demonstrates the diversity within the Portland food cart field itself, which is commonly portrayed as space for ethnic entrepreneurs and a means of enjoying an exotic experience for foodies. Understanding these differences can enhance the potential for equity in planning efforts geared toward maintaining the mobile food movement and enhancing local AFNs in Portland. Theoretically speaking, this study presents nuanced account of the social worlds and everyday practices of food cart owners serving ethnic food in pods outside of downtown and the inner-ring neighborhoods of Portland, and how their varying dispositions (or habitus) and situated knowledges relate to the larger field of Portland food carts and the sourcing of food products from the Pacific Northwest region. Finally, this research practically speaks to ongoing local and regional food sustainability plans to increase AFN participation that can benefit from social science inquiries that examine participation and access to resources. 


\subsection{Study Limitations \& Future Research Directions}

This study represents a snapshot in time of a slice of an urban mobile food phenomenon wherein carts change pod locations (and even locations within a pod), experience seasonal droughts of customers, and sometimes have to close operations entirely. The very notion of "mobile" in the food cart phenomenon means subject to change, no matter how stationery pod arrangements might seem from an everyday perspective. Many cart owners are on month-to-month leases that could be terminated on short notice. Lots used for cart pods may be redeveloped for the right price, as was the case with a former pod on Southeast Division Street and may be the fate of the popular Cartopia pod on Southeast $12^{\text {th }}$ Ave. \& Hawthorne (Njus, 2014).

Given the qualitative nature of the data collected and the focus on the Eastern Portland sample area, this study is limited in generalizability. I argue, however, that since the study focuses on ethnic foods, it addressed implicit questions of whether or not local/regional food is commensurate with exotic culinary experiences. In terms of local food sourcing, cart owners serving various ethnic cuisines are more likely to find barriers to local sourcing from a geographic standpoint at multiple scales: certain products are simply not grown in the Pacific Northwest or are too costly purchase based on the purchasing power of their neighborhood customers. Relating this to the larger population of food carts, my analysis of these particular small-scale food supply networks investigates potentially competing goals for food cart owners, such a providing culturally specific cuisine at low cost for ethnic groups and buying local. Further research would benefit from more interviews with cart owners representing additional ethnicities that we 
not able to be incorporated into this study. Interviews could be conducted in additional languages (e.g. Thai, Vietnamese) in addition to the Spanish-speaking owners interviewed in this study.

Furthering this research agenda would valuable for enhancing our collective understanding of both the food cart phenomenon and the local food movement in Portland. If food carts are to continue to be a policy darling for the city of Portland and viewed as a replicable model elsewhere (e.g. Newman \& Burnett, 2013), more practical tools are needed for evaluating current policies and prescriptions, such as those outlines in Climate Action Plan and the Portland Plan. As a community, this research will also help us articulate and pose bigger research questions (such as "Are food carts sustainable?" or "Are there differences among food carts and small restaurants in terms of their participation in the local food movement") for which we currently lack empirical data.

\subsection{Policy Implications for Food Carts \& AFN in Portland}

Essentially, we really don't know much about supply chain sustainability at the small retail level, especially the subset of food cart owners that represent a relatively diverse class of small business entrepreneurs within the Portland area. The development of metrics to assess the goals of increasing the consumption of local and regional food was deemed lagging in the Climate Action Plan's Year Two Progress report. ${ }^{36}$ This report also noted that metrics currently exist, albeit in nascent stages, for assessing directto-consumer (DTC) relationships like farmers markets and CSAs. Inclusive policies that

\footnotetext{
${ }^{36}$ This is an action item of the Climate Action Plan's Goal 15, "Significantly increase the consumption of local food" (City of Portland \& Multnomah County, 2012). I review food systems policies related to local and regional sourcing in Chapter 3.
} 
aspire to increase the consumption of local and regional food would benefit from additional information on the direct-to-vendor (DTV) relationships between producers and small-scale foodservice establishments, especially given the conclusions in this study and other studies on how Portland food carts are positively contributing to the city's overall economic and cultural capital.

Given the nebulous understanding of sustainability in DTV supply chain networks, assessments of food supply chain sustainability should be based on situated perspectives of lived inhabitants. The conclusions from this study can be used to inform a larger survey of food cart owners' supply habits could reveal more general trends related to supply chain sustainability for the larger food cart scene in Portland. Such research would build upon this qualitative inquiry and develop quantitative measures in order to test relationships among key variables, such as the percentage of local food purchased by cart owner by type of food product (e.g., meat, dairy, grains, fruit, non-perishable items), type of cuisine, and pod location. There are several themes to be explored further, including more insight into how the daily routines and networks inhabited by ethnic food cart owners function, and what opportunities might exist for more ethnic food carts to engage in the local AFNs in the greater Portland metro area. Morgan (2013: 181) described this as sequential research design, where an in-depth qualitative inquiry (the core method) provides detailed information to operationalize variables for quantitative measure (the follow-up method). A larger sample from across Portland would help compare the less dense and more residential Eastern Portland area to the more densely commercial downtown and inner-ring areas, increasing our understanding of the food cart 
phenomenon and sustainability in additional urban settings within Portland. The results of such a quantitative follow-up to this qualitative inquiry would represent a baseline understanding of the supply chain sustainability of Portland food carts that could be examined for statistical relationships between variables. Together, this collection of quantitative and qualitative data could paint a more substantial and nuanced picture of the food cart supply chain and help the community better understand the locality of these networks.

What types of policies or interventions might foster an increased participation in local AFNs by ethnic food cart owners? Results of the Toronto A La Cart mobile food experiment suggest caution when moving away from more laissez faire approaches to street food regulation (as is the case in Portland) toward stricter regulations on food quality and supply source, even when such regulations specifically target ethnic diversity and the use of local ingredients (Hawkins \& Associates, 2011; Toronto Life, 2012). Based on the conclusions from my inquiry, food cart owners serving ethnic food in Eastern Portland could potentially increase the amount of food served that is sourced from local/regional producers, but cost, seasonality, and general access to information on local AFNs in Portland are persistent barriers. Even under ideal conditions for local sourcing (e.g. no cost differences), there will still be a substantial amount of ingredients (an estimated 20 percent) that are simply not grown in the Pacific Northwest region and must be obtained from imported sources like Fubonn or tiendas that sell exotic food supplies. Developing relationships with local/regional food producers is a somewhat more difficult task for food cart owners as compared to restaurants, as the latter offer 
more consistent purchasing patterns at higher volumes that can justify the time required by producers to cultivate and maintain these DTV relationships. Furthermore, the cart owners interviewed in Eastern Portland indicated that a purchasing cooperation within food cart pods (an arrangement could potentially increase the volume of food cart supplies obtained from local/regional sources) would not be feasible for various reasons such as lack of food storage, the need for specific products, and competition with other carts.

Thus, policies and programs aimed at addressing the relative lack of local and regional food purchased by ethnic food cart owners in Portland should be more descriptive than prescriptive in nature to address the informational barriers that were highlighted in this situation. Minority and immigrant food cart entrepreneurs could benefit from more information on local AFNs in Portland, including descriptions of the locavore food scene and potential opportunities for participation that are translated into variety of languages (Spanish, Thai, Mandarin, Russian). In addition, many existing and prospective cart owners would benefit from specific resources on Portland-area food suppliers that offer local/regional products. Such information could be disseminated through channels that cart owners are already using for information, including the consulates of their home countries and chambers of commerce specific or other community-based organizations that are specific to their places of origin. Focusing on informational resources would not entail a shift in regulatory enforcement on the part of county health regulations or local zoning laws related to mobile food. Such support would merely attempt to level the playing field of information access and cultural literacy 
on local AFNs in Portland that already distinguishes certain human actors from others in this situation. 


\section{References}

Agyeman, J. \& H. Sobel. (2013). "From Loncheras to Lobsta Love - Food Trucks, Cultural Identity and Social Justice." Just Sustainabilities.

http://julianagyeman.com/2013/06/from-loncheras-to-lobsta-love-food-truckscultural-identity-and-social-justice/

Alkon, A. H., \& Agyeman, J. (2011). Cultivating food justice: race, class, and sustainability. Cambridge, Mass. MIT Press.

Allen, P. (2008). Mining for justice in the food system: perceptions, practices, and possibilities. Agriculture and Human Values, 25(2), 157-161.

Allen, P. (2010). Realizing justice in local food systems. Cambridge Journal of Regions, Economy and Society, 3(2), 295-308.

Beasley--Murray, J. (2012). "Value and Capital in Bourdieu and Marx." In Pierre Bourdieu: Fieldwork in Culture. Ed. Brown, N. \& Szeman, I. 100-119. Rowman \& Littlefield.

Born, B., \& Purcell, M. (2006). Avoiding the local trap scale and food systems in planning research. Journal of Planning Education and Research, 26(2), 195-207.

Bourdieu, P. (1986). "The forms of capital." In Handbook of Theory and Research for the Sociology of Education. Ed. Richardson, J. 241-258. New York: Greenwood.

Bourdieu, P. (1998). Practical Reason: On the Theory of Action. Stanford University Press.

Butler, J. (2001). “Giving an Account of Oneself.” Diacritics, 31 (4) (February 6): 22-40.

Carder, P. C. (2002). Promoting independence: An analysis of assisted living facility marketing materials. Research on Aging, 24(1), 106-123.

---- (2008). Managing Medication in Assisted Living: A Situational Analysis. Journal of Ethnographic \& Qualitative Research, 3(1).

City of Portland. (2014a). Portland Plan Population and Demographics. Available online at: http://www.portlandonline.com/portlandplan/index.cfm?c=52257.

---- (2014b). “6a. Population by Neighborhood.” Portland Plan Population and Demographics. Available online at: http://www.portlandonline.com/portlandplan/index.cfm?c=52257\&a=288621.

--- (2014c). “6b. Foreign Born Population by District Coalition.” 
http://www.portlandonline.com/portlandplan/index.cfm?c=52257\&a=288627

--- (2014d). “Food Carts in Portland.” http://www.portlandoregon.gov/bps/52798.

City of Portland. (2012). The Portland Plan. Available online at http://www.portlandonline.com/portlandplan/.

City of Portland. (2010). "A Challenge for Portland's Food Carts!" http://www.portlandoregon.gov/bps/article/310400?\&archive=2010-07.

City of Portland \& Multnomah County. (2009). Climate Action Plan. Available online at: http://www.portlandoregon.gov/bps/49989.

---- (2012). Climate Action Plan Year Two Progress Report.

City of Portland Bureau of Planning \& Sustainability (BPS). (March 2009). East Portland Historical Overview \& Historic Preservation Study. Available online at: http://www.portlandoregon.gov/bps/article/214638.

----- (2009). "Food Systems." Portland Plan Background Report: Fall 2009. http://www.portlandonline.com/portlandplan/index.cfm?a=273154.

Culverwell, Wendy. (2013). "Retail Revival: Food carts add to downtown's vibrancy." 16 Dec. 2013. http://www.katu.com/news/local/Retail-Revival-Food-carts-add-todowntowns-vibrancy-236108191.html

DeLind, Laura B. (2010). "Are Local Food and the Local Food Movement Taking Us Where We Want to Go? Or Are We Hitching Our Wagons to the Wrong Stars?" Agriculture and Human Values, 28, no. 2 (February 22, 2010): 273-283.

Donald, B., \& Blay-Palmer, A. (2006). The urban creative-food economy: producing food for the urban elite or social inclusion opportunity? Environment and planning A, 38(10), 1901.

Duara, N. (2011). "Go For the Food: Take culinary world tour with Portland's food carts, from Thailand to Georgia." Associated Press. 4 Mar 2014. http://bigstory.ap.org/article/go-food-portland-food-carts-cross-borders

DuPuis, E. M., Harrison, J. L., \& Goodman, D. (2011). Just food. Cultivating food justice: race, class, and sustainability, Eds. A.H. Alkon \& J. Agyeman, 283-307.

DuPuis, E. Melanie, and David Goodman. (2005). "Should We Go 'home' to Eat?: Toward a Reflexive Politics of Localism." Journal of Rural Studies, (21)3: 359371. 
"Farm." (2001). Portlandia. IFC. 21 Jan. 2011. Television. http://www.imdb.com/title/tt1785082/.

Ferretti, E. (2011). "Portland's Gourmet Food Cart Phenomenon.” Fox News. 20 May 2011. http://www.foxnews.com/leisure/2011/05/10/portlands-gourmet-food-cartphenomenon/\#ixzz1M3ObpRpN

Flores, Alma. (2010). "Portland Food Carts. Twitter Me This: Taco Trucks and Cupcakes - Gentrification, Evolution or Something in Between?" American Planning Association: Contesting the Streets Conference. May 2010. Available online at: http://www.portlandoregon.gov/bps/article/303162.

Giombolini, K. J., Chambers, K. J., Schlegel, S. A., \& Dunne, J. B. (2011). Testing the local reality- does the Willamette Valley growing region produce enough to meet the needs of the local population? Agriculture \& Human Values, 28 (247-262).

Guthman, J. (2003). Fast food/organic food: Reflexive tastes and the making of 'yuppie chow'. Social \& Cultural Geography, 4(1), 45-58.

Guthman, J. (2008). Bringing good food to others: investigating the subjects of alternative food practice. cultural geographies, 15(4), 431-447.

Hawkins \& Associates. (2011). "City of Toronto: A Review of Toronto A La Cart Project." 4 April 2011. http://www.toronto.ca/legdocs/mmis/2011/ex/bgrd/backgroundfile-37419.pdf

Heying, C. (2010). Brew to Bikes: Portland's Artisan Economy. Ooligan Press.

Hodder, I. (1994). The interpretation of documents and material culture. In NK Denzin, YS Lincoln (Eds.) Handbook of Qualitative Research, 393-402.

Johnston, J. (2008). The citizen-consumer hybrid: ideological tensions and the case of Whole Foods Market. Theory and Society, 37(3), 229-270.

Kapell, H., P. Katon, A. Koski, J. Li, C. Price \& K. Thalhammer. (2008). "Food Cartology: Rethinking Urban Spaces and People Places." Master of Urban and Regional Planning Workshop Projects. Paper 42. http://pdxscholar.library.pdx.edu/usp_murp/42.

Krueger, R., \& Gibbs, D. (Eds.). (2007). The sustainable development paradox: urban political economy in the United States and Europe. Guilford Press.

Latour, B. (2005). Reassembling the Social-An Introduction to Actor-Network-Theory. Oxford University Press. 
Levkoe, C. Z. (2011). Towards a transformative food politics. Local Environment, 16(7), 687-705.

Lockie, S. (2009). Responsibility and agency within alternative food networks: assembling the "citizen consumer". Agriculture and Human Values, 26 (3), 193201.

Manning, P. K., \& Cullum-Swan, B. (1994). Narrative, content, and semiotic analysis. Handbook of qualitative research, 463-477.

McClintock, N. (2014). Radical, reformist, and garden-variety neoliberal: coming to terms with urban agriculture's contradictions. Local Environment, 19(2), 147-171.

Mares, T. M., \& Peña, D. G. (2011). Environmental and Food Justice: Toward Local, Slow and Deep Food Systems. In Cultivating food justice: Race, class, and sustainability. Ed. Alkon, A. \& Agyeman, J. 197-220. MIT Press.

National League of Cities (NLC). (2013). Food on Wheels: Mobile Vending Goes Mainstream. Best Practices for Integrating Food Trucks Into City Life. Available online at:

http://www.nlc.org/Documents/Find\%20City\%20Solutions/Research\%20Innovati on/Economic\%20Development/FoodTruckReport2013_Final_9-26.pdf.

Navarro, Z. (2006). In search of a cultural interpretation of power: the contribution of Pierre Bourdieu. IDS Bulletin, 37(6), 11-22.

Prichep, D. (2011). "Living the Dream: The Truth About Life Inside Food Carts." National Public Radio. 8 July 2011. http://www.npr.org/templates/story/story.php?storyId=137716312\&sc $=t w \& c c=s h$ are.

Portland Public Schools (PPS). (2014). "Enrollment Reports." Data and Policy Analysis. http://www.pps.k12.or.us/departments/data-analysis/4605.htm.

Pullen, JP. (N.d.) "Food cart tours: Stroll downtown streets and savor the culinary offerings at every corner." Travel Portland. http://www.travelportland.com/article/food-cart-tours/

Pullman, M. E., Maloni, M. J., \& Carter, C. R. (2009). Food for thought: social versus environmental sustainability practices and performance outcomes. Journal of Supply Chain Management, 45(4), 38-54. 
Rommelmann, Nancy. (2009). “The Art of the Street Cart.” Bon Appétit, September 2009.

http://www.bonappetit.com/recipes/slideshows/2009/09/the_art_of_the_street_car t.

Raight, PK \& Mc Clenaghan. (2012). "Food carts filling buildings as well as bellies." Portland Business Journal. 10 December 2012. http://www.bizjournals.com/portland/blog/real-estate-daily/2012/12/food-cartsfill-buildings-as-well-as.html? $\mathrm{s}=$ \&page $=$ all

Slocum, R. (2007). Whiteness, space and alternative food practice. Geoforum, 38(3), $520-533$.

Talbot, M. (2012). "Stumptown Girl: An indie-rock star satirizes hipster culture, on Portlandia." The New Yorker. 2 January 2012. http://www.newyorker.com/reporting/2012/01/02/120102fa fact talbot?currentPa $\mathrm{ge}=$ all.

Toronto Life. (2012). “Toronto A La Cart.” http://www.torontolife.com/tag/toronto-a-lacart/.

Turner, Jennifer, "The View from the Table: An Analysis of Participant Reactions to Community-Based Dialogues on Food and Justice" (2013). Dissertations and Theses. Paper 1092. http://pdxscholar.library.pdx.edu/open_access_etds/1092.

Weiner, M.B. (2011). "World's Best Street Food." US News and World Report. 7 Jan 2011. http://travel.usnews.com/features/Worlds_Best_Street_Food/

Zimmer, E. (2012). "Portland Street Food: 10 Carts We Really Love.” Serious Eats. 2 Oct. $2012 \mathrm{http} / / / \mathrm{www}$. seriouseats.com/2012/10/what-is-the-best-street-food-inportland-carts-pods.html 
Appendix A: Portland Food Cart \& Demographic Maps 


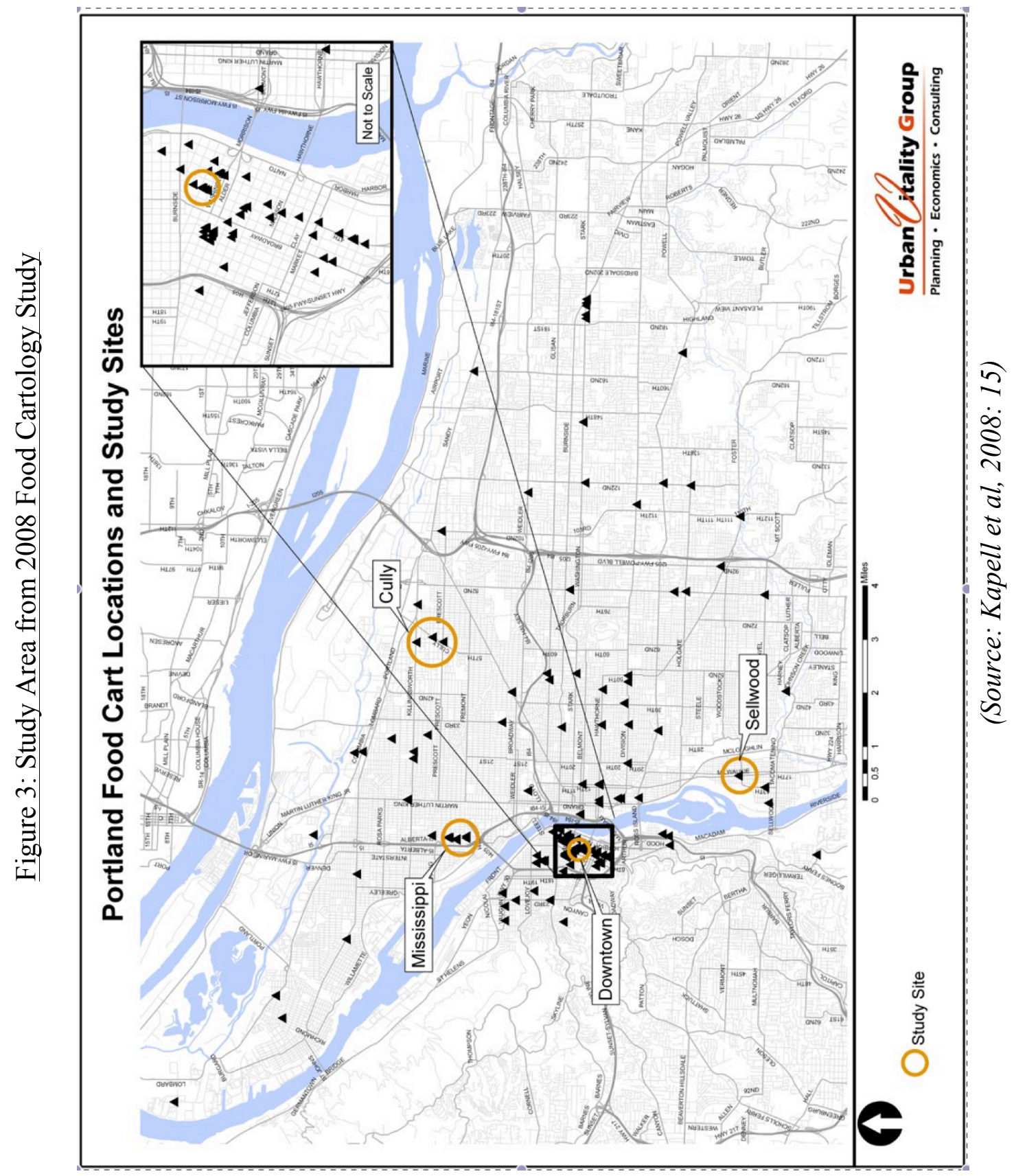




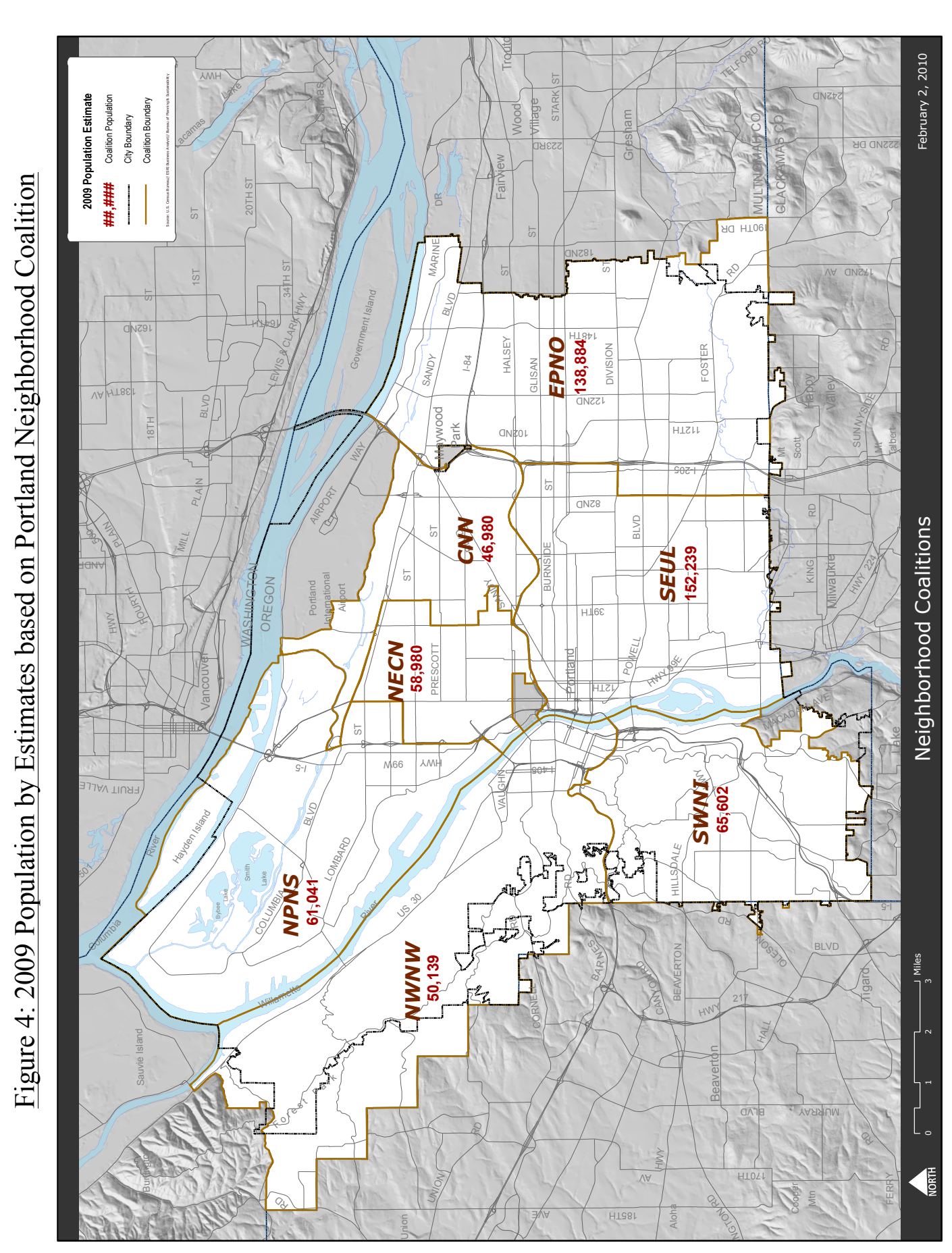

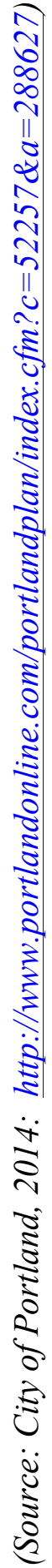




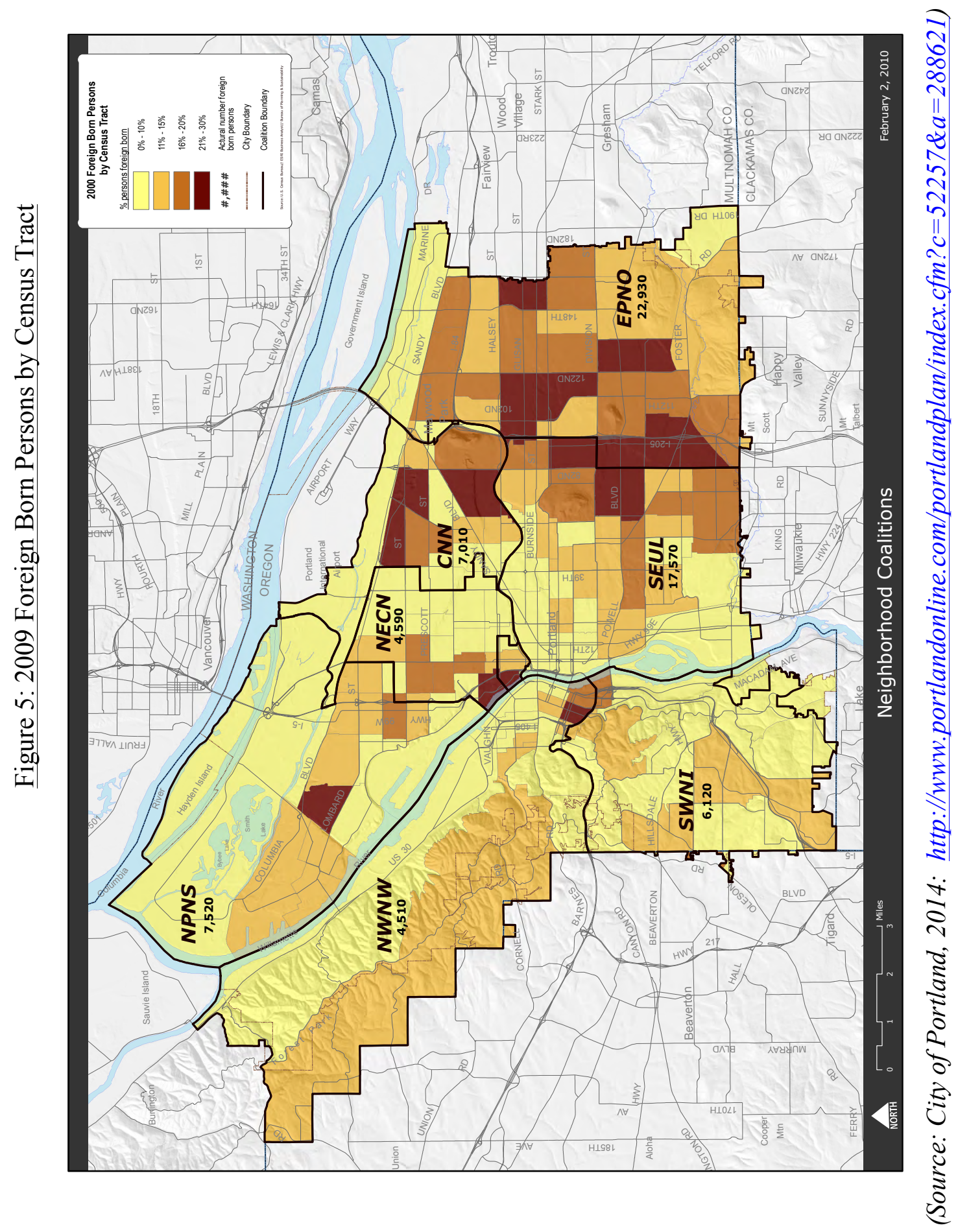


Appendix B: Menu Materials from Food Carts Inventoried 


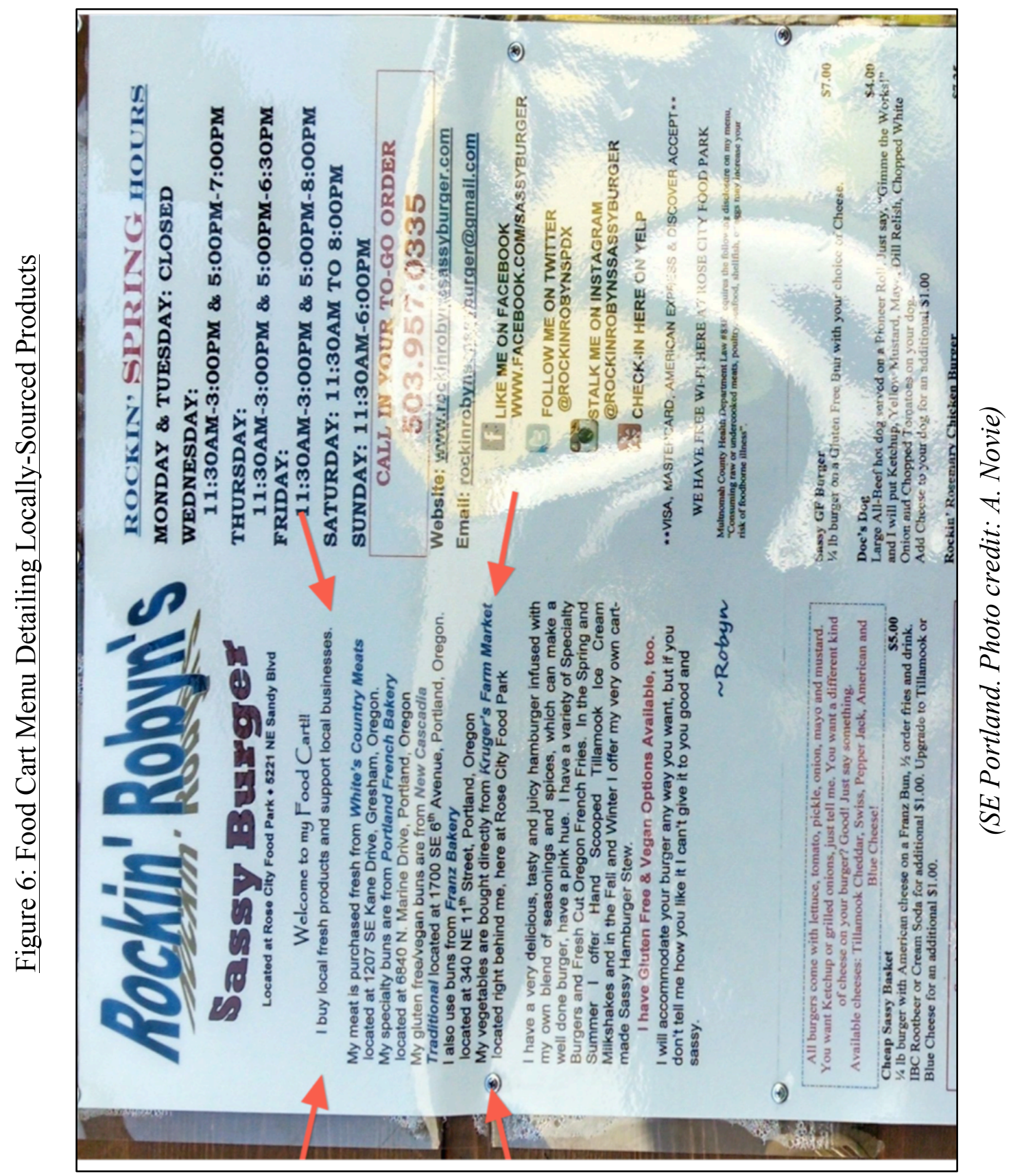




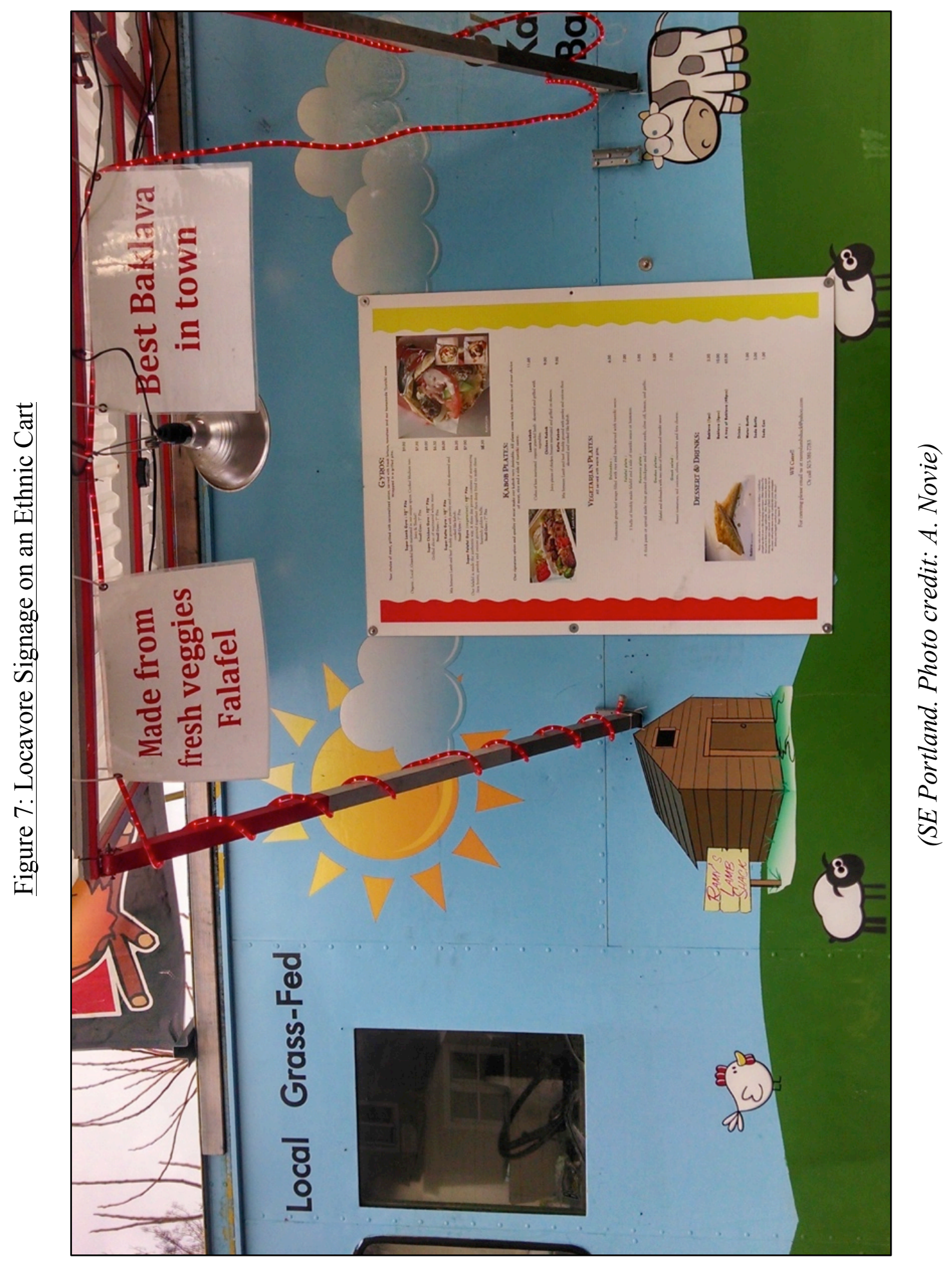


Figure 8: Hand-Written Cart Menu (No Details on Sourcing)

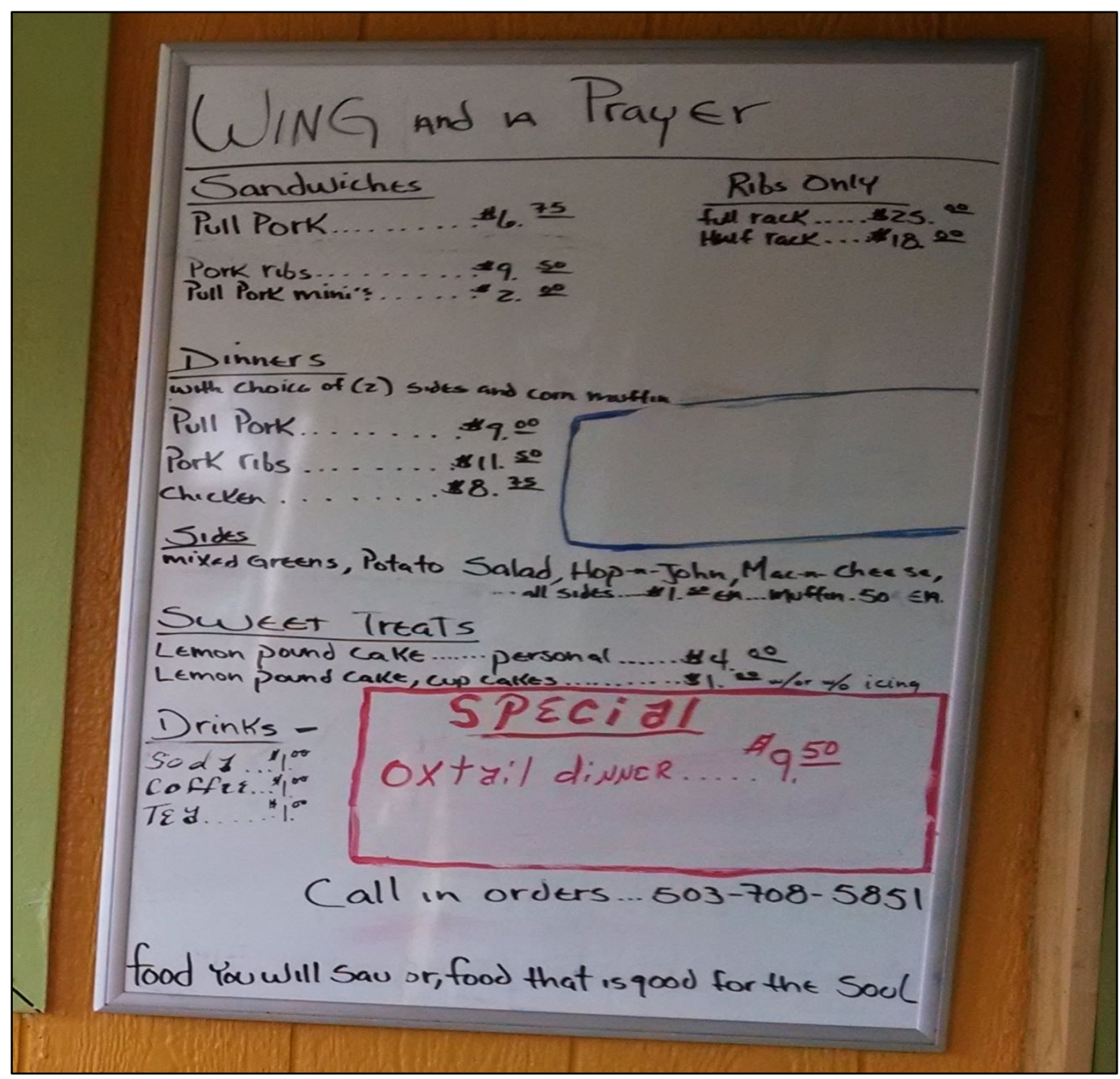

(NE Portland. Photo credit: A. Novie) 
Figure 9: Compost instructions and bins for pod patrons

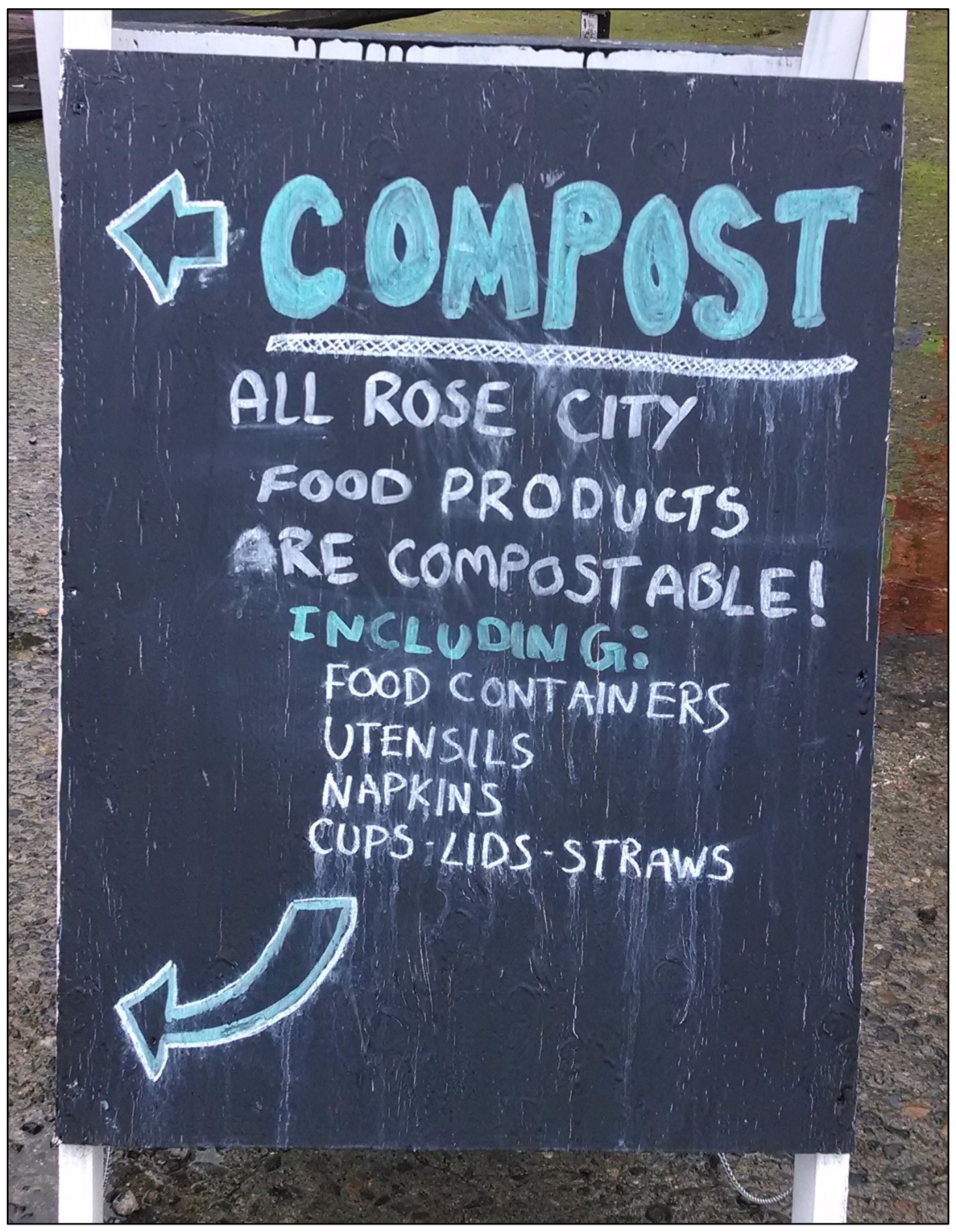

(NE Portland. Photo credit: A. Novie) 
Appendix C: In-Depth Interview Guide 
1. Describe your motivations to start a food cart.

2. How long have you been operating this cart?

3. How do you market your food cart?

4. Tell me about the types of messages you focus on when advertising.

5. Where you obtain your food supplies? [Direct marketing, suppliers, etc.]

6. [If subject of "local" not broached] What do you consider to be "local" in terms of your food supplies?

7. Do you use local food products in your cart?

8. If you source certain items locally, do you advertise this? [E.g. "We use mostly locally-grown food.’']

9. What are your perceived benefits of sourcing local? Any disadvantages?

10. What is your definition of local in terms of food supplies?

11. What are your thoughts on Portland as a "foodie" and sustainability hub or capital?

a. Do you consider yourself to be a part of this conversation or movement? 